OPEN ACCESS

Edited by:

Supratik Kar

Jackson State University,

United States

Reviewed by:

Prakash P. Praharaj,

National Institute of Technology

Rourkela, India

Natália Cruz-Martins,

Universidade do Porto, Portugal

Sujit Kumar Bhutia,

National Institute of Technology

Rourkela, India

*Correspondence:

Md. Ataur Rahman

ataur1981rahman@hotmail.com

Hyewhon Rhim

hrhim@kist.re.kr

${ }^{\dagger}$ These authors have contributed equally to this work

Specialty section:

This article was submitted to

Ethnopharmacology,

a section of the journal

Frontiers in Pharmacology

Received: 09 December 2020

Accepted: 18 March 2021

Published: 07 May 2021

Citation:

Rahman MA, Hannan MA, Dash $R$ Rahman $M D H$, Islam R, Uddin MJ, Sohag AAM, Rahman MH and Rhim H (2021) Phytochemicals as a

Complement to Cancer

Chemotherapy: Pharmacological Modulation of the Autophagy-

Apoptosis Pathway.

Front. Pharmacol. 12:639628.

doi: 10.3389/fphar.2021.639628

\section{Phytochemicals as a Complement to Cancer Chemotherapy: Pharmacological Modulation of the Autophagy-Apoptosis Pathway}

\author{
Md. Ataur Rahman ${ }^{1,2 * t}$, Md. Abdul Hannan ${ }^{3,4 \dagger}$, Raju Dash ${ }^{3}$, MD. Hasanur Rahman ${ }^{5,9}$, \\ Rokibul Islam ${ }^{7,8}$, Md Jamal Uddin ${ }^{6,9}$, Abdullah Al Mamun Sohag ${ }^{4}$, Md. Habibur Rahman ${ }^{10}$ \\ and Hyewhon Rhim ${ }^{1,11 *}$
}

\begin{abstract}
${ }^{1}$ Center for Neuroscience, Korea Institute of Science and Technology (KIST), Seoul, South Korea, ${ }^{2}$ Global Biotechnology \& Biomedical Research Network (GBBRN), Department of Biotechnology and Genetic Engineering, Faculty of Biological Sciences, Islamic University, Kushtia, Bangladesh, ${ }^{3}$ Department of Anatomy, Dongguk University College of Medicine, Gyeongju, South Korea, ${ }^{4}$ Department of Biochemistry and Molecular Biology, Bangladesh Agricultural University, Mymensingh, Bangladesh, ${ }^{5}$ Department of Biotechnology and Genetic Engineering, Bangabandhu Sheikh Mujibur Rahman Science and Technology University, Gopalganj, Bangladesh, ${ }^{6}$ ABEx Bio-Research Center, Dhaka, Bangladesh, ${ }^{7}$ Department of Biotechnology and Genetic Engineering, Faculty of Biological Sciences, Islamic University, Kushtia, Bangladesh, ${ }^{8}$ Department of Biochemistry, College of Medicine, Hallym University, Chuncheon-si, South Korea, ${ }^{9}$ Graduate School of Pharmaceutical Sciences, College of Pharmacy, Ewha Womans University, Seoul, South Korea, ${ }^{10}$ Department of Global Medical Science, Wonju College of Medicine, Yonsei University, Seoul, South Korea, ${ }^{11}$ Division of Bio-Medical Science and Technology, KIST School, Korea University of Science and Technology (UST), Seoul, South Korea
\end{abstract}

Bioactive plant derived compounds are important for a wide range of therapeutic applications, and some display promising anticancer properties. Further evidence suggests that phytochemicals modulate autophagy and apoptosis, the two crucial cellular pathways involved in the underlying pathobiology of cancer development and regulation. Pharmacological targeting of autophagy and apoptosis signaling using phytochemicals therefore offers a promising strategy that is complementary to conventional cancer chemotherapy. In this review, we sought to highlight the molecular basis of the autophagic-apoptotic pathway to understand its implication in the pathobiology of cancer, and explore this fundamental cellular process as a druggable anticancer target. We also aimed to present recent advances and address the limitations faced in the therapeutic development of phytochemical-based anticancer drugs.

Keywords: phytochemicals, pharmacology, apoptosis, autophagy, anticancer

\section{INTRODUCTION}

Cancer is responsible for 9.6 million deaths in 2018 and is listed as the second leading cause of death globally. Cancer thus poses a pivotal public health concern worldwide (WHO, 2018). During the 20th century, the cancer death rate was found to markedly increase, primarily because of abnormal lifestyles, such as excessive tobacco use (Siegel et al., 2020), physical and chemical carcinogens (Bhatia et al., 2020), alcohol use (Sanford et al., 2020), unhealthy diet (Khaltaev and Axelrod, 2020), and biological carcinogens (Hartwig et al., 2020). Delaying cancer treatment initiation increases patient mortality (Hanna et al., 2020). However, increased awareness about the need for lifestyle modification, early detection, and treatment may have contributed to a decline in cancer prevalence (i.e., by 1.5\%, on average, per year from 2013 to 2017) (Henley et al., 2020). Cancer treatment options, 
such as chemotherapy, radiation therapy, hormone therapy, gene therapy, immunotherapy, photodynamic therapy, targeted therapy, surgery, palliative care, and a combination of these, are increasing in both number and efficiency across multiple types of cancer and for various patients (Markham et al., 2020). The main goal of cancer therapy is to stimulate the death of abnormal cells and preserve normal cells (Schirrmacher, 2019). Chemotherapy is the backbone of many cancer treatments. It aids in the reduction of tumor size and kills cancer cells at primary sites or metastasizing sites (Sak, 2012; Alfarouk et al., 2015). However, response to treatment varies substantially according to the type of cancer or even with the same type of cancer (Sak, 2012). Resistance to chemotherapeutic agents poses a major problem in cancer treatment, ultimately limiting the efficiency of anticancer drugs, which causes therapeutic failure and eventually death (Alfarouk et al., 2015). Chemotherapy resistance can be attributed to numerous mechanisms, including multi-drug resistance, alterations of cell death mechanisms (autophagy and apoptosis), changes in drug metabolism, epigenetic and drug targets, enhanced DNA repair and gene amplification, tumor cell heterogeneity, drug efflux and metabolism, and tumor microenvironment stressinduced genetic or epigenetic alterations as a cellular response to drug exposure (Wang et al., 2019). Among these mechanisms, alterations in autophagy ('self-eating') and apoptosis ('selfkilling'), which are two self-destructive processes that have propelled scientific innovation, are the vital causes of chemotherapy resistance (Thorburn et al., 2014). Autophagy, an evolutionarily conserved and regulated cellular recycling mechanism, has emerged as a key player in metabolic and therapeutic stresses. In fact, this mechanism attempts to maintain or restore metabolic homeostasis via the catabolic degradation of unnecessary proteins and injured or aged organelles (Santana-Codina et al., 2017). The role of autophagy in cancer treatment is paradoxical; it may act as a pro-survival or pro-death mechanism to counteract or mediate the cytotoxic effect of anticancer agents (Santana-Codina et al., 2017). Autophagy primarily functions as a tumor suppressor by modulating reactive oxygen species (ROS) within cells and maintaining genetic instability (Levine and Kroemer, 2008). Moreover, accumulating evidence suggests that faulty autophagy is linked to malignant transformation of cancer stem cells (Moosavi et al., 2018). Under these conditions, autophagy stimulation might be a critical approach to halt early tumor formation and development (Moosavi et al., 2018). However, autophagy can promote the growth and survival of current tumors during migration and epithelial-tomesenchymal transition. Further, this process can help cancer stem cells escape immune surveillance and make cancer cells resistant to anoikis (Moosavi et al., 2018; Rahman et al., 2020). In this regard, inhibition of autophagy increases chemotherapyinduced cytotoxicity. Therefore, autophagy, a double-edge sword that works in a context-dependent manner, blocks the early stages of tumorigenesis while becoming a driver of tumor invasion and metastasis at later stages (Moosavi et al., 2018). The molecular mechanisms regulating the switch between these different modes of action are poorly understood (Kardideh et al., 2019). Nonetheless, the interplay between apoptosis and autophagy can be leveraged to improve cancer therapy (Tompkins and Thorburn, 2019). Cancer cells become chemotherapy-resistant by escaping some of the potential apoptotic mechanisms, such as downregulated pro-apoptotic signals, upregulated anti-apoptotic signals, and faulty apoptosis initiation and implementation. However, the functional relationship between apoptosis and autophagy is complex and has recently been deciphered at the molecular level. Therefore, modulating the key factors in the autophagic and apoptotic pathways may be a novel therapeutic strategy for enhancing chemotherapy efficiency.

The potential roles of phytochemicals in the modulation of autophagy and apoptosis have recently been reviewed (Deng et al., 2019). However, autophagy and apoptosis induction and/or inhibition are extremely complex processes that require thorough exploration. Nevertheless, a better understanding of the crosstalk between autophagy and apoptosis will enable further developments of novel anticancer therapeutic strategies. In this review, we summarize the molecular mechanisms of autophagy and apoptosis in cancer. Given the pivotal role of phytochemicals in cancer therapy, we sought to discuss various phytochemicals that could regulate autophagy and apoptosis-related signaling pathways to enhance cancer chemotherapy outcomes.

\section{METHODS}

A literature-based search was accomplished to collect published databases and relevant methodological contributions of the molecular mechanism of phytochemicals in autophagyapoptosis modulation and cancer prevention has been conducted using PubMed, Scopus, Google Scholar, Web of Science, and Google that includes all original research articles written in English on multifunctional role of phytochemicals. Searching was conducted using various keywords including autophagy, apoptosis, natural compounds, cancer, phytochemical, neurodegenerative diseases, solid tumors and lymphomas, heart/cardiovascular diseases, perspectives role autophagy in cancer therapy and so on. All figures were generated using Adobe Illustrator software.

\section{MOLECULAR MECHANISM OF AUTOPHAGY IN CANCER}

Autophagy is a cellular process that breaks down or degrades unwanted or aggregated dysfunctional cellular components through fusion with lysosomes; this cellular process is known to play an essential role in maintaining cellular function as well as homeostasis (Krishnan et al., 2020). Autophagy preserves an active interlink in cell defense as well as a cytostatic link in cancer cell progression (Rahman and Rhim, 2017). Generally, the process of autophagy might be introduced by the generation of preautophagosomal structures known as phagophore assembly sites (PAS) (Hurley and Young, 2017; Rahman and Rhim, 2017). Phosphatidylinositol 3-phosphate (PI3K), which is associated with 


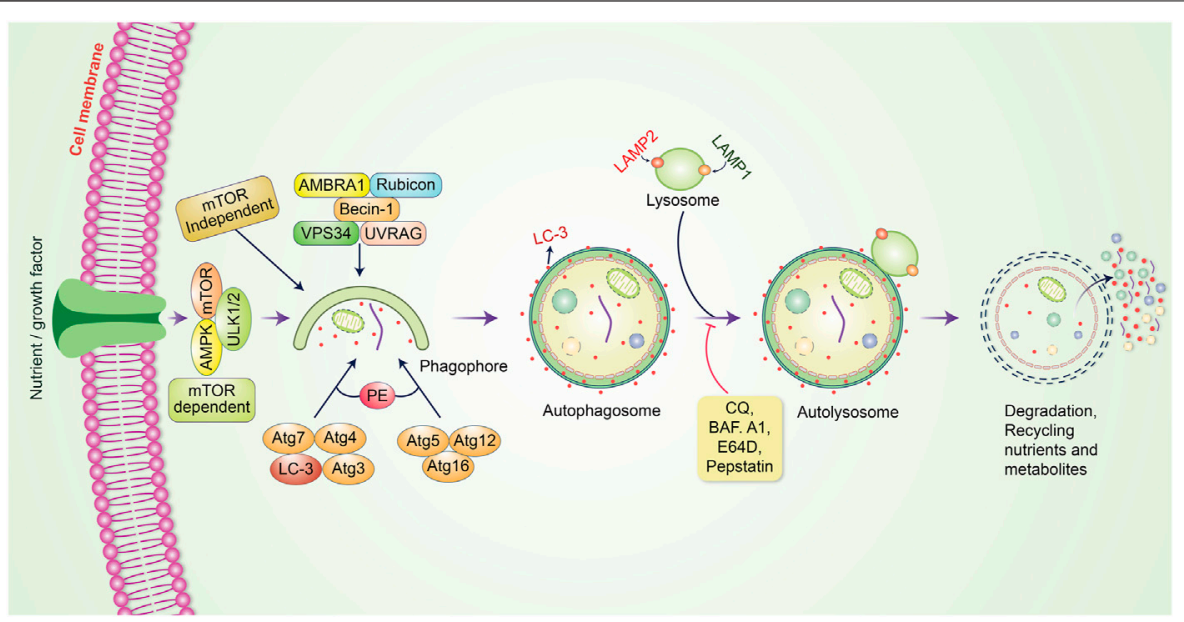

FIGURE 1 | Molecular mechanism of the autophagic pathway. Autophagy is initiated by the formation of a pre-autophagosomal structure. PI3K-AMPK and mammalian target of rapamycin (mTOR) contribute to the formation of the pre-autophagosomal structure. ULK1, Vps34 and the Beclin-1 complex help to activate phagophore formation. After phagophore nucleation is elongated, subsequent binding to autophagosome occurs. Binding between mature autophagosome and lysosome results in autolysosome formation. Finally, autolysosomes are eliminated through acid hydrolases, which produce nutrients and recycling metabolites.

the endoplasmic reticulum (ER), plays an essential role in the initiation of PAS formation (Kotani et al., 2018). AMP-activated protein kinase (AMPK), mammalian target of rapamycin (mTOR), and unc-51 like autophagy activating kinase-1 (ULK1) have been demonstrated to facilitate phagophore formation during autophagy induction (Alers et al., 2012), with Vps34, Vps15/p150, and Beclin-1 as recruiters for phagophore formation (Velazquez and Jackson, 2018). After phagophores are formed, phagocytosis occurs. This process is subsequently followed by expansion and sealing to elongate the membrane for autophagosome formation (Rubinsztein et al., 2012). Mature autophagosomes bind to lysosomes, resulting in autolysosome formation (Kardideh et al., 2019). Eventually, autolysosomes containing inner cargos are degraded by acid hydrolases and produce nutrients; other recycling metabolites subsequently preserve cellular homeostasis (Figure 1). The fate of cancer cells is thus dependent on autophagy (Wei and Huang, 2019). Autophagy decides whether the cancer is suppressed or promoted under certain conditions. mTOR plays an important role in protecting or activating oncogenic cells through the induction of autophagy. However, chemotherapy drugs have been found to suppress tumor cells by modulating autophagic pathways. Furthermore, inhibition of this pathway regulates cancer progression, and the influence of autophagy becomes either a cellular survival or death function (Jung et al., 2020). The metabolism of malignant cells is intensely altered to retain their proliferation and survival under adverse microenvironmental conditions. Autophagy plays an essential role in maintaining metabolic adaptations in cancer cells (Goldsmith et al., 2014). Although autophagy is recognized to sustain neoplastic cell metabolism under stress, the mutual association between cancer cell metabolism and autophagy remains unknown. mTOR and AMPK have been identified as the main signaling components that modulate autophagy via the regulation of amino acid and glucose levels (Alers et al., 2012). However, specific metabolites, ROS, growth factors, palmitate, oxygen concentration, ATP to ADP ratio, specific amino acid levels, and oncogenes regulate autophagy initiation and autophagosome formation. Further, they regulate this fine balance by assimilating these autophagy-related signals in cancer (Singh and Cuervo, 2011; Panda et al., 2015). Prominently, autophagy has been frequently identified to play a "dual role" as it can either hinder or stimulate cancer initiation and progression (Patra et al., 2020; Rahman et al., 2020a). In the present review, we outline the dual role of autophagy in tumorigenesis and emphasize our recent understanding of autophagy regulation of cancer cell activation and metabolism to control tumor growth and progression.

\section{MOLECULAR MECHANISM OF APOPTOSIS IN CANCER}

Apoptosis or programmed cell death is one of the predominant strategies for blocking or avoiding cancer or cancer formation (Lopez and Tait, 2015). Focusing on apoptosis is most effective for different cancer types because escaping apoptosis is a trademark of cancer and is indifferent to the type of cancer. Apoptosis is generally a central pathway that is associated with intrinsic and extrinsic pathways (Elmore, 2007). However, these extrinsic and intrinsic pathways could be involved in the same station, which is known as the execution pathway (Goldar et al., 2015) (Figure 2). To initiate apoptosis in apoptotic cells, the extrinsic pathway uses extracellular signals to induce apoptosis via stimulation of Fas ligand, tumor necrosis factor (TNF), and TNF-related apoptosisinducing ligand (TRAIL), which interact with the extracellular transmembrane domain of death receptors (DR) (Guicciardi and Gores, 2009). Finally, caspases participate in the extrinsic pathway and are generally typified as starter, stimulator, or executioner caspases owing to their involvement and participation in the apoptotic signaling pathways. The intrinsic apoptotic pathway is directly involved in mitochondria-mediated proteins. Different stimuli, such as adequate $\mathrm{Ca}^{2+}$, impaired DNA molecules, 


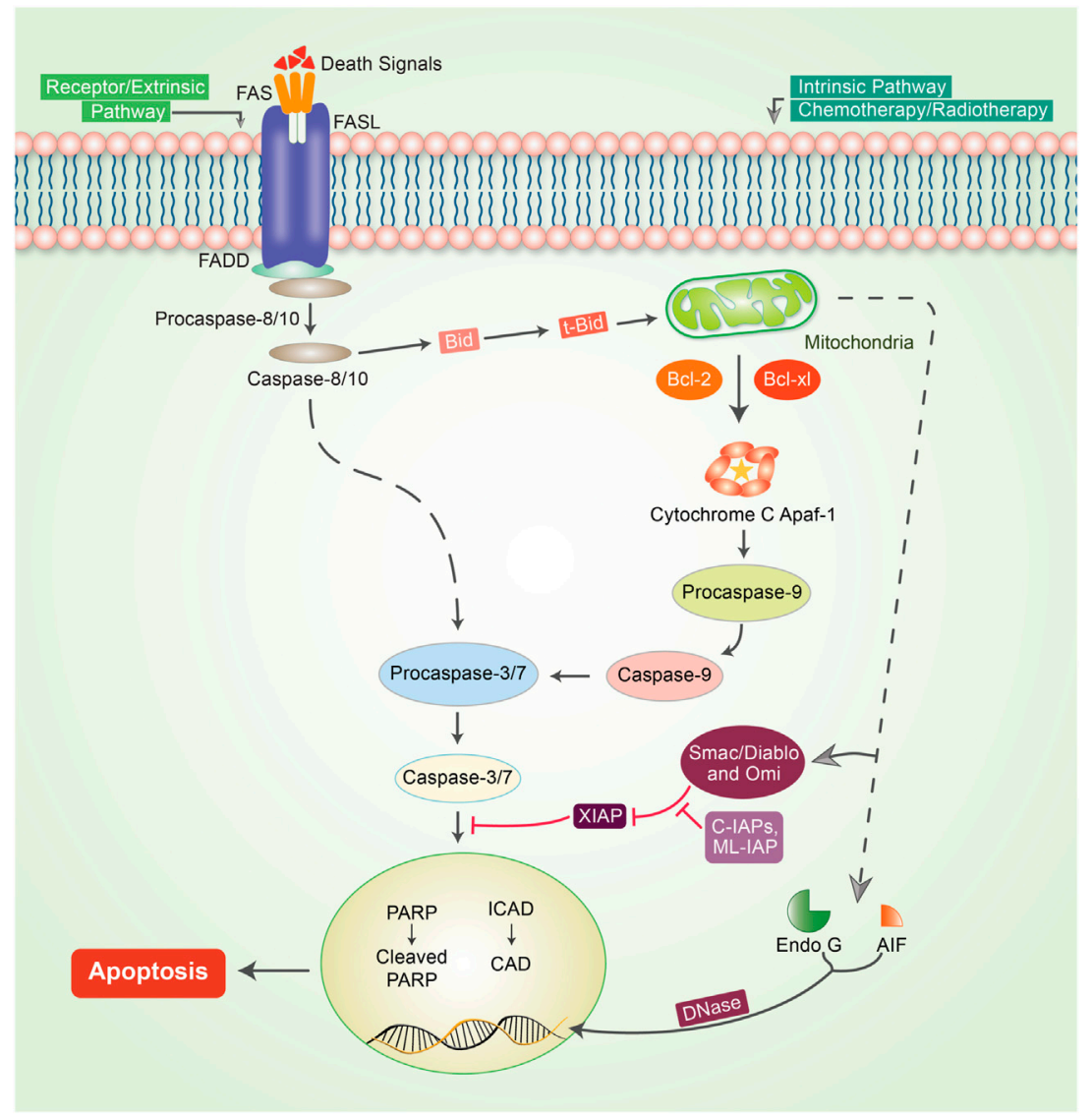

FIGURE 2 | Mechanism of the apoptotic pathway in cancer. To initiate apoptosis, two central pathways are involved in this mechanism: the intrinsic pathway and extrinsic pathway. The extrinsic pathway of apoptosis is well defined by the TNF- $\alpha$ /TNFR1 and FasL/FasR models. Herein, the death receptor is induced by an adaptor protein; adaptor proteins are comprised of FADD (Fas-associated death domain) and TRADD (TNF receptor-associated death domain). The signaling that occurs through the extrinsic pathway causes the attachment of DRs to specific death ligands (DLs), thereby forming a death-inducing signaling cascade (DISC). The complex pathway of caspase-8 activation follows a predefined system that actively enables caspase-8 to detach from the DISC, whether or not the pro-domain of caspase- 8 is retained as part of the DISC to initiate the signaling phases of apoptosis. However, in most apoptotic cells, proteins are customarily engaged in intrinsic phases that involve caspase-9, SMAC/DIABLO, Bcl-2, Bcl-w, Aven, Nox, and MYC. Mitochondrial dysfunction is followed by the loss of inner membrane mitochondrial potential, adequate formation of superoxide ions, impaired mitochondrial biogenesis formation, release of intra-membrane proteins, and matrix calcium glutathione burst, which enumerate the important potential for cancer therapeutic strategies by triggering the intrinsic phases of apoptosis in tumor cells. The execution phase of apoptosis initiator caspases, such as caspase-8/-9 or caspase-activated dnase (CAD), Poly (ADP-ribose polymerase (PARP), and other caspases such as caspase-3, $-6,-7$, and caspase-10, are typified as upregulator or executioner caspases. Caspase-3 is the most essential and effective of all effector caspases because it can be activated by all initiator caspases.

oxidative stress (OS), surplus oxidants, deprivation of growth factors, and drug treatment and irradiation, have been associated with this pathway (Ghavami et al., 2004; Hassan et al., 2020). When Bax/Bak is incorporated into the mitochondrial membrane, it triggers the release of cytochrome $c$ from the mitochondrial inner membrane into the cytosol (Kim, 2005). The intrinsic pathway of cell death is caused by Bcl-2 family proteins, which are pro-apoptotic and antiapoptotic proteins, including $\mathrm{Bcl}-2$ and $\mathrm{Bcl}-\mathrm{xL}$ (Ghobrial et al., 2005). Apaf-1 and procaspase- 9 combine with cytochrome $c$ to form an apoptosome. Both mitochondria-dependent (intrinsic) and independent (extrinsic) pathways are connected at the same point, called the execution pathway (Elmore, 2007). The extrinsic and intrinsic phases are linked at the same point after caspase- 8 is triggered. Activated caspase- 8 in the extrinsic mechanism regulates the activation of $\mathrm{BH} 3$ interacting-domain (BID), a pro-apoptotic protein alternatively called $\mathrm{BH} 3$-only protein. BID then stimulates and oligomerizes the pro-apoptotic proteins, BAX and BAK, resulting in an intrinsic apoptotic phase (Green and Llambi, 2015).

\section{PHYTOCHEMICALS MODULATE AUTOPHAGY-APOPTOSIS SIGNALING IN SEVERAL CANCERS}

Autophagy plays an essential role in cancer treatment, especially in chemotherapy, by removing dysfunctional organelles and intracellular components and inducing lysosomal degradation. This self-digestion mechanism strengthens cellular defense to protect cells from various intracellular and extracellular stresses 


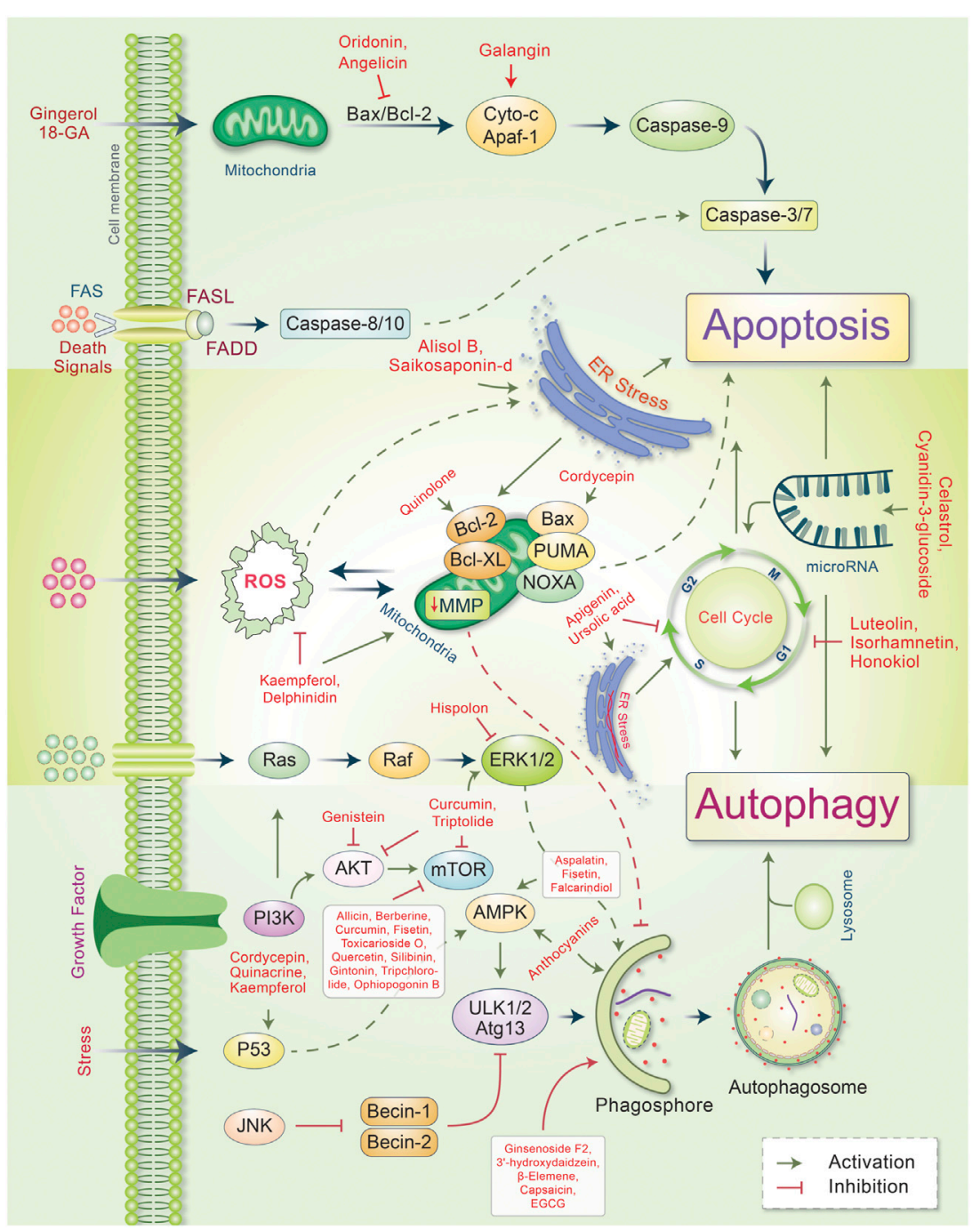

FIGURE 3 | Major phytochemicals induce the signal transduction pathways that regulate autophagic and apoptotic cell death in cancer. Phytochemicals have been found to activate both the intrinsic and extrinsic apoptotic pathways by inducing a dysfunction in mitichrondria-caspase-9 and FAS-ligand-caspase-8 mediated apoptotic cell death, respectively. Phytochemicals induce ER stress and apoptotic cell death. However, some phytochemicals modulate mitichrondrial biogenesis and ensure apoptosis-autophagic cell death. Phytochemicals regulate the cell cycle and microRNA as well as cause apoptosis-autophagic cell death in cancer cells. Some phytochemicals activate autophagic signaling and inhibits cell growth and autophagy. For a detailed explanation, see the text.

and regulate redox balance to provide genomic and cytoplasmic stability. Emerging evidence supports the dual role of autophagy in cancer (i.e., as a promoter and an inhibitor of tumor development). However, the induction of autophagy in cancer is still a potential strategy; this is because it induces type II programmed cell death. During cancer initiation, autophagy regulators, such as $\mathrm{mTOR}$ and AMPK, are negatively modulated by tumor-suppressing factors, which cause autophagy induction (Comel et al., 2014). However, these autophagy regulators are activated by several oncogenes that suppress autophagy and promote cancer formation (Choi et al., 2013). Autophagy also suppresses carcinogenesis by regulating ROS, and excessive ROS production promotes tumor generation (Ávalos et al., 2014; Filomeni et al., 2015). Owing to their multifaceted therapeutic activities, phytochemicals have proven to be promising for treating many cancers (Mitra and Dash, 2018). In some cases, metabolites and synthetic products from natural compounds have demonstrated better chemopreventive effects than their original compounds (Aung et al., 2017). Our model and emerging evidence indicate that phytochemicals targeting the autophagic-apoptotic pathways are promising agents for cancer treatment for both pathways, or are dependent- and -independent of target-specific molecular mechanisms in cancer cells (Figure 3). Several phytochemicals and their autophagic-apoptotic effects are summarized in Table 1.

\section{Phytochemicals in Autophagy Signaling}

Apigenin is a flavonoid derivative that modulates several kinase pathways and inhibits the cell cycle at the G2/M phase. Studies 
TABLE 1 | Phytochemicals that activate autophagy and apoptosis in various in vitro and in vivo cancer models.

\begin{tabular}{|c|c|c|c|c|}
\hline Phytochemicals & $\begin{array}{l}\text { Doses/ } \\
\text { Conc }\end{array}$ & Cancer model & Molecular effects & References \\
\hline Resveratrol & $10-100 \mu \mathrm{M}$ & $\begin{array}{l}\text { Human colon carcinoma cell lines } \\
\text { SW480, SW620, B103, and } \\
\text { HCT116 }\end{array}$ & Activate procaspase-3, 8/FADD & Delmas et al. (2003); Rahman et al. (2012a) \\
\hline Eriocalyxin B (EriB) & $1.4 \mu \mathrm{M}$ & $\begin{array}{l}\text { Human pancreatic cancer } \\
\text { cellPANC-1, SW1990 CAPAN-2, } \\
\text { and CAPAN-1 }\end{array}$ & $\begin{array}{l}\text { Caspase } 8,9 \text { activation and } \\
\text { downstream regulation of caspases } \\
3,7, \text { PARP }\end{array}$ & Li et al. (2012) \\
\hline$\beta$-Elemene & $10 \mu \mathrm{M}$ & $\begin{array}{l}\text { Human breast cancer cell lines } \\
\text { Bcap37, MBA-MD-231 }\end{array}$ & Conservation of LC3-I to LC3-II & Guan et al. (2014) \\
\hline Oblongifolin C & $15 \mu \mathrm{M}$ & $\begin{array}{l}\text { Human breast carcinoma cell lines } \\
\text { HeLa or MEF }\end{array}$ & $\begin{array}{l}\text { Activation of CASP3 and cleaved } \\
\text { PARP }\end{array}$ & Lao et al. (2014) \\
\hline Apigenin & $10 \mu \mathrm{M}$ & $\begin{array}{l}\text { Colorectal cancer cells HCT-116, } \\
\text { SW480, HT-29 and LoVo }\end{array}$ & Activate NAG-1, p53, p21 & Zhong et al. (2010) \\
\hline Allicin & $1 \mu \mathrm{g} / \mathrm{ml}$ & $\begin{array}{l}\text { Human gastric cancer cell line } \\
\text { MGC-803, BGC-823 and SGC- } \\
7901\end{array}$ & $\begin{array}{l}\text { Increase expression of p38 and } \\
\text { cleaved Of caspase } 3\end{array}$ & Zhang et al. (2015) \\
\hline Anthocyanins & $50 \mu \mathrm{M}$ & $\begin{array}{l}\text { Breast cancer cell lines MCF-MDA- } \\
\text { MB-231 and MDA-MB- } 453\end{array}$ & $\begin{array}{l}\text { Inhibit the expression of VEGF, } \\
\text { suppressed the MMP-9,MMP-2 and } \\
\text { UPA expression }\end{array}$ & Hui et al. (2010) \\
\hline Aspalathin & $0.2 \mu \mathrm{M}$ & Ovarian cancer cell Caov-3 & $\begin{array}{l}\text { Inhibit Dox, decrease expression of } \\
\text { p53 and induce AMPK and Foxo1 }\end{array}$ & Lin et al. (2017) \\
\hline Baicalein & $200 \mu \mathrm{M}$ & $\begin{array}{l}\text { Human HCC cell lines SMMC-772 } \\
\text { and Bel-7402 }\end{array}$ & $\begin{array}{l}\text { Downregulate } \mathrm{Bcl} 2 \text {, increase ER } \\
\text { stress }\end{array}$ & Wang et al. (2014) \\
\hline Berberine & $100 \mathrm{nM}$ & $\begin{array}{l}\text { Human glioma cell lines U251 and } \\
\text { U87 GBM }\end{array}$ & Inhibition of AMPK/mTOR/ULK1 & $\begin{array}{l}\text { Peng et al. (2008); Wang et al. (2010); Yu et al. } \\
\text { (2014); Guamán Ortiz et al. (2015); Wang et al. } \\
\text { (2016a) }\end{array}$ \\
\hline Capsaicin & $150 \mu \mathrm{M}$ & $\begin{array}{l}\text { Human nasopharyngeal } \\
\text { carcinoma cell line NPC-TW01 }\end{array}$ & $\begin{array}{l}\text { Downstream of PI3K/Akt/mTOR, } \\
\text { increase caspase-3 activity }\end{array}$ & Lin et al. (2017b) \\
\hline Celastrol & $1.5 \mu \mathrm{M}$ & $\begin{array}{l}\text { Human prostate cancer cell lines } \\
\text { LNCaP, 22Rv1, DU145 and PC-3 }\end{array}$ & Upstream of miR-101 & Guo et al. (2015) \\
\hline Cordycepin & $200 \mu \mathrm{M}$ & $\begin{array}{l}\text { Human brain cancer cellSH-SY5Y } \\
\text { and U-251 }\end{array}$ & Upregulates ROS, p53, and LC3II & Chaicharoenaudomrung et al. (2018) \\
\hline Curcumin & $25 \mu \mathrm{M}$ & $\begin{array}{l}\text { Malignant mesotheloma cancer } \\
\text { cell line MM-B1, H-Meso-1, and } \\
\text { MM-F1 }\end{array}$ & $\begin{array}{l}\text { Increase } \mathrm{Bax} / \mathrm{bcl}-2 \text { ratio, } \mathrm{p} 53 \\
\text { expression, activation of caspase } 9 \text {, } \\
\text { cleavage of PARP-1 }\end{array}$ & Masuelli et al. (2017) \\
\hline $\begin{array}{l}\text { Epigallocatechin gallate } \\
\text { (EGCG) }\end{array}$ & $100 \mathrm{nM}$ & Vascular endothelial cell line U-937 & $\begin{array}{l}\text { Reduce TNF- } \alpha \text {, inhibit VCAM1, LC3A, } \\
\text { LC3B }\end{array}$ & Yamagata et al. (2015) \\
\hline Evodiamine & $10 \mu \mathrm{M}$ & Gastric cancer cell line SGC-7901 & $\begin{array}{l}\text { Activates beclin-2, Bax, } \\
\text { downregulates } \mathrm{Bcl}-2\end{array}$ & Rasul et al. (2012) \\
\hline Fisetin & $40-120 \mu \mathrm{M}$ & $\begin{array}{l}\text { Prostate cancer cell lines PC3 and } \\
\text { DU145 }\end{array}$ & $\begin{array}{l}\text { Supressed Mtor and inhibit Akt, } \\
\text { activate AMPK }\end{array}$ & Suh et al. (2010) \\
\hline Genistein & $50-100 \mu \mathrm{M}$ & Ovarian cancer cell line A2780 & Reduces Akt/mTOR phosphorylation & Gossner et al. (2007) \\
\hline Gingerol & $300 \mu \mathrm{M}$ & $\begin{array}{l}\text { Human colon cancer cell lines SW- } \\
480 \text { and HCT116 }\end{array}$ & $\begin{array}{l}\text { Inhibition of JNK, ERK1-2, and P38 } \\
\text { MAPK }\end{array}$ & $\begin{array}{l}\text { Shukla and Singh, (2007); Baliga et al. (2011); } \\
\text { Radhakrishnan et al. (2014) }\end{array}$ \\
\hline Ginsenoside F2 & $100 \mu \mathrm{M}$ & Breast cancer cell lines MCF-7 & $\begin{array}{l}\text { Elevated Atg-7 } \\
\text { Cleaved PARP }\end{array}$ & Mai et al. (2012) \\
\hline Hispolon & $25-100 \mu \mathrm{M}$ & $\begin{array}{l}\text { Cervical cancer cell lines Hela and } \\
\text { SiHa }\end{array}$ & $\begin{array}{l}\text { Downregulated lysosomal protease } \\
\text { Cathepsin S(CTSS) }\end{array}$ & Chen et al. (2012) \\
\hline $\begin{array}{l}3^{\prime} \text {-hydroxydaidzein } \\
\left(3^{\prime}-\text { ODI }\right)\end{array}$ & $100 \mu \mathrm{M}$ & Mouse melanoma cell line B16F1 & Reduce the $a-\mathrm{MSH}$ & Kim et al. (2013) \\
\hline Toxicarioside $\mathrm{O}$ & $50 \mathrm{nM}$ & $\begin{array}{l}\text { Human colorectal cancer cell lines } \\
\text { HCT116 and SW } 480\end{array}$ & $\begin{array}{l}\text { Inhibition of the Akt/mTOR } \\
\text { Upstream SIRT1 } \uparrow\end{array}$ & Huang et al. (2017) \\
\hline Falcarindiol & $6 \mu \mathrm{M}$ & $\begin{array}{l}\text { Human breast cancer cell lines } \\
\text { MDA-MB-231,MDA-MB-468 and } \\
\text { Her2 }\end{array}$ & FAD induce expression of GRP78 & $\begin{array}{l}\text { Minto and Blacklock, (2008); Jin et al. (2012); } \\
\text { Lu et al. (2017) }\end{array}$ \\
\hline Oleanolic acid & $100 \mu \mathrm{g} / \mathrm{ml}$ & $\begin{array}{l}\text { Human pancreatic cancer cell line } \\
\text { Panc-28 }\end{array}$ & Modulate JNK and mTOR pathway & Pollier and Goossens, (2012); Liu et al. (2014) \\
\hline Honokiol & $40 \mu \mathrm{M}$ & $\begin{array}{l}\text { Human glioblastoma cell lines } \\
\text { LN229, GBM8401 and U373 }\end{array}$ & Reduction of p-PI3K, p-Akt and Ki67 & Cheng et al. (2016) \\
\hline Magnolol & $40 \mu \mathrm{M}$ & $\begin{array}{l}\text { Human glioblastoma cell lines } \\
\text { LN229, GBM8401 and U373 }\end{array}$ & Reduction of p-PI3K, p-Akt and Ki67 & Cheng et al. (2016) \\
\hline Alisol B & $30 \mu \mathrm{M}$ & $\begin{array}{l}\text { Breast cancer cell lines MCF-7, } \\
\text { SK-BR-3, and HeLa }\end{array}$ & Activation of $\mathrm{Ca} 2+/ \mathrm{AMPK} / \mathrm{Mtor}$ & Law et al. (2010) \\
\hline
\end{tabular}

(Continued on following page) 
TABLE 1 | (Continued) Phytochemicals that activate autophagy and apoptosis in various in vitro and in vivo cancer models.

\begin{tabular}{|c|c|c|c|c|}
\hline Phytochemicals & $\begin{array}{l}\text { Doses/ } \\
\text { Conc }\end{array}$ & Cancer model & Molecular effects & References \\
\hline Luteolin & $100 \mu \mathrm{M}$ & Human liver cancer SMMC-7721 & $\begin{array}{l}\text { Increase expression of caspase-8, } \\
\text { decrease bcl-2 }\end{array}$ & Cao et al. (2017) \\
\hline a-Mangostin & $5-10 \mu \mathrm{M}$ & $\begin{array}{l}\text { Human brain cancer cell lines, } \\
\text { GBM8401 and DBTRG05MG }\end{array}$ & Activation of AMPK & Chao et al. (2011) \\
\hline Oridonin & 8-32 $\mu \mathrm{mol} / \mathrm{L}$ & $\begin{array}{l}\text { Human hepatocellular carcinoma } \\
\text { cell line BEL-7402 }\end{array}$ & $\begin{array}{l}\text { Activation of caspase- } 3 \\
\text { Down-regulation of } \mathrm{Bcl}-2 \text { and } \mathrm{Up} \text { - } \\
\text { regulation of } \mathrm{Bax}\end{array}$ & Zhang et al. (2006) \\
\hline Quercetin & $15 \mu \mathrm{M}$ & $\begin{array}{l}\text { Lymphoma cell lines BC3, BCBL1 } \\
\text { and BC1 }\end{array}$ & $\begin{array}{l}\text { Inhibits PI3K/Akt/mTOR and Wnt/ } \\
\beta \text {-catenin }\end{array}$ & Granato et al. (2017) \\
\hline Rottlerin & $1-2 \mu \mathrm{M}$ & $\begin{array}{l}\text { Breast cancer cell lines CD44/ } \\
\text { CD24 }\end{array}$ & Enhance expression of LC3 & Kumar et al. (2013) \\
\hline 6-Shogaol & $55.4 \mu \mathrm{M}$ & Lung cancer cell line A549 & $\begin{array}{l}\text { Inhibition af Akt and mTOR } \\
\text { downstream }\end{array}$ & Hung et al. (2009) \\
\hline Silibinin (silybin) & $50 \mu \mathrm{M}$ & RCC cell lines $A C H N$ and 786-O & Inhibit mTOR and activate AMPK & Li et al. (2015) \\
\hline Sulforaphane & $40 \mu \mathrm{M}$ & $\begin{array}{l}\text { Human pancreatic cancer cell lines } \\
\text { MIA PaCa-2,Panc-1 }\end{array}$ & Increase ROS level & Naumann et al. (2011) \\
\hline$\gamma$-tocotrienol & $10 \mu \mathrm{mol} / \mathrm{L}$ & $\begin{array}{l}\text { Breast cancer cell lines MCF-7 and } \\
\text { MDA-MB-231 }\end{array}$ & $\begin{array}{l}\text { Activate AMPK, down regulate Ang- } \\
1 / \text { Tie- } 2\end{array}$ & Ling et al. (2012); Tang et al. (2019) \\
\hline Thymoquinone & $40-60 \mu \mathrm{M}$ & $\begin{array}{l}\text { Oral cancer cell lines } \\
\text { SASVO3,SCC-4, OCT,SAS }\end{array}$ & $\begin{array}{l}\text { Increase expression of LC3-II, Bax } \\
\text { expression }\end{array}$ & Chu et al. (2014) \\
\hline Tripchlorolide & $200 \mathrm{nM}$ & Lung cancer cell line A549/DDP & Inhibition of PI3K/Akt/mTOR & Chen et al. (2017a) \\
\hline Tetrandrine & $0-4 \mu \mathrm{M}$ & $\begin{array}{l}\text { Hepatocellular carcinoma cell lines } \\
\text { Huh7, HCCLM9 and Hep3B }\end{array}$ & $\begin{array}{l}\text { Inhibits Wnt } / \beta \text {-catenin } \\
\text { Decreases MTA1 }\end{array}$ & Zhang et al. (2018) \\
\hline N-desmethyldauricine & $150 \mu \mathrm{M}$ & Lung cancer cell line H1299 & $\begin{array}{l}\text { Inhibition of Ulk-1/PERK/AMPK/ } \\
\text { mTOR }\end{array}$ & Law et al. (2017) \\
\hline Quinacrine & $15 \mu \mathrm{M}$ & $\begin{array}{l}\text { Colon cancer cell lines HCT-116/ } \\
\text { HCT-116/HCT-116 }\end{array}$ & $\begin{array}{l}\text { Activation of p53, p21, and inhibition } \\
\text { of topoisomerase }\end{array}$ & Mohapatra et al. (2012) \\
\hline Chloroquine & $50 \mu \mathrm{M}$ & $\begin{array}{l}\text { Pancreatic cancer cell line } \\
\text { MiaPaCa2 and S2VP10 }\end{array}$ & Decrease the level of $\mathrm{O}_{2}$ & Frieboes et al. (2014) \\
\hline Tangeritin & $10 \mu \mathrm{M}$ & $\begin{array}{l}\text { Breast cancer cell lines MCF7, } \\
\text { MDA-MB-468 and MCF10A }\end{array}$ & $\begin{array}{l}\text { Induce CYP1 and CYP1A1/CYP1B1 } \\
\text { protein expression }\end{array}$ & Surichan et al. (2018) \\
\hline Myricetin & $100 \mu \mathrm{M} / \mathrm{L}$ & $\begin{array}{l}\text { Prostate cancer cell lines PC3, } \\
\text { DU145 }\end{array}$ & $\begin{array}{l}\text { Knockdown the interaction between } \\
\text { P1M1/CXCR4 }\end{array}$ & Ye et al. (2018) \\
\hline Galangin & $15 \mu \mathrm{M}$ & $\begin{array}{l}\text { Human kidney cancer cell line } \\
\text { A498 }\end{array}$ & Inhibition of PI3K/Akt/mTOR signaling & Zhu et al. (2018) \\
\hline Isorhamnetin & $100 \mu \mathrm{M}$ & $\begin{array}{l}\text { Colon cancer cell lines HCT116 } \\
\text { and SW480 }\end{array}$ & Increase ROS & Wu et al. (2018) \\
\hline Hesperetin & $350 \mu \mathrm{M}$ & Lung cancer cell line H522 & $\begin{array}{l}\text { Knockdown caspase-3/9,p53,Bax } \\
\text { Upregulate Fas, FADD and } \\
\text { caspase- } 8\end{array}$ & Elango et al. (2018) \\
\hline Delphinidin & $80 \mu \mathrm{M}$ & $\begin{array}{l}\text { Breast cancer cell lines MDA-MB- } \\
453 \text { and BT474 }\end{array}$ & $\begin{array}{l}\text { Suppression of mTOR } \\
\text { Activation of the AMPK }\end{array}$ & Chen et al. (2018) \\
\hline $\begin{array}{l}\text { Epigallocatechingallate } \\
\text { (EGCG) }\end{array}$ & $500 \mu \mathrm{M}$ & $\begin{array}{l}\text { Human glioblastoma cell lines } \\
\text { T98G and U87MG }\end{array}$ & Increase ROS & Grube et al. (2018) \\
\hline $\begin{array}{l}\text { Epicatechin-3- } \\
\text { O-gallate (ECG) }\end{array}$ & $36 \mu \mathrm{M}$ & $\begin{array}{l}\text { Prostate cancer cell lines LNCaP } \\
\text { and PC-3 }\end{array}$ & $\begin{array}{l}\text { Diminished the progression of } \\
\text { carcinofenic cell }\end{array}$ & Siddiqui et al. (2011); Stadlbauer et al. (2018) \\
\hline $\begin{array}{l}\text { Cyanidin-3- } \\
\text { glucoside (C3G) }\end{array}$ & $20 \mu \mathrm{M}$ & $\begin{array}{l}\text { Human breast cancer MDA-MB- } \\
231 \text { and Hs-578T }\end{array}$ & $\begin{array}{l}\text { Inhibiting STAT3/NEGF and miR124 } \\
\text { mediated downregulation STAT3 }\end{array}$ & Ma and Ning, (2019) \\
\hline $\begin{array}{l}\text { Benzyl isothiocyanate } \\
\text { (BITC) }\end{array}$ & $6.5 \mu \mathrm{M}$ & $\begin{array}{l}\text { Pancreatic cell lines BxPC-3 and } \\
\text { PanC-1 }\end{array}$ & $\begin{array}{l}\text { Decrease the phosphorylation of } \\
\text { PI3K/Akt/FOXO1/PDK1/mTOR/ } \\
\text { FOXO3a }\end{array}$ & Boreddy et al. (2011) \\
\hline $\begin{array}{l}\text { Phenethyl isothiocyanates } \\
\text { (PEITC) }\end{array}$ & $10 \mu \mathrm{M}$ & $\begin{array}{l}\text { Breast cancer cell lines MDA-MB- } \\
231 \text { and MCF-7 }\end{array}$ & $\begin{array}{l}\text { Reduction of HER2, EGFR and } \\
\text { STAT3 expression }\end{array}$ & Gupta and Srivastava, (2012) \\
\hline Piperlongumine (PL) & $6 \mu \mathrm{M}$ & $\begin{array}{l}\text { Lung cancer cell lines A549 and } \\
\text { A549/DTX }\end{array}$ & Regulate PI3K/Akt/mTOR & $\begin{array}{l}\text { Bezerra et al. (2008); Raj et al. (2011); Wang et al. } \\
\text { (2015) }\end{array}$ \\
\hline Saikosaponin-d & $10 \mu \mathrm{M}$ & $\begin{array}{l}\text { Breast cancer cell lines HeLa and } \\
\text { MCF-7 }\end{array}$ & $\begin{array}{l}\text { Calcium mobilization, induce } \\
\text { CaMKK } \beta-A M P K-m T O R\end{array}$ & $\begin{array}{l}\text { Hsu et al. (2004); Tundis et al. (2009); Wong et al. } \\
\text { (2013) }\end{array}$ \\
\hline Guttiferone K & $20 \mu \mathrm{M}$ & Human HCCs HuH7 and HepG2 & $\begin{array}{l}\text { Reduce phosphorylation of Akt } \\
\text { /mTOR, increase ROS }\end{array}$ & $\begin{array}{l}\text { Xu et al. (2008) } \\
\text { Wu et al. (2015) }\end{array}$ \\
\hline Licochalcone A & 20 or $50 \mu \mathrm{M}$ & Breast cancer cell line MCF-7 & $\begin{array}{l}\text { Suppression of PI3K/Akt/mTOR } \\
\text { pathway }\end{array}$ & Xue et al. (2018) \\
\hline Ophiopogonin B & $10 \mu \mathrm{M}$ & $\begin{array}{l}\text { Lung cancer (NSCLC) cell lines } \\
\mathrm{NCl}-\mathrm{H} 157 \text { and } \mathrm{NCl}-\mathrm{H} 460\end{array}$ & Inhibition of PI3K, Akt, mTOR & Chen et al. (2013a) \\
\hline
\end{tabular}

(Continued on following page) 
TABLE 1 | (Continued) Phytochemicals that activate autophagy and apoptosis in various in vitro and in vivo cancer models.

\begin{tabular}{|c|c|c|c|c|}
\hline Phytochemicals & $\begin{array}{l}\text { Doses/ } \\
\text { Conc }\end{array}$ & Cancer model & Molecular effects & References \\
\hline Norcantharidin & $40 \mu \mathrm{M}$ & $\begin{array}{l}\text { Human MHCC-97H }(97 \mathrm{H}) \text { and } \\
\text { HepG2 HCC cells }\end{array}$ & Inhibition of c-Met, mTOR & Sun et al. (2017a) \\
\hline Juglanin & $10 \mu \mathrm{M}$ & $\begin{array}{l}\text { Breast cancer cell lines MCF-7 and } \\
\text { SKBR3 }\end{array}$ & Regulation of ROS, JNK & Sun et al. (2017b) \\
\hline Isoliquiritigenin & $25 \mu \mathrm{M}$ & $\begin{array}{l}\text { Human ovarian cancer cell lines, } \\
\text { OVCAR5 and ES-2 }\end{array}$ & $\begin{array}{l}\text { Cleaved caspase-3, increased LC3B- } \\
\text { II, and Beclin-1 level }\end{array}$ & Chen et al. (2017b) \\
\hline Cucurbitacin B & $200 \mu \mathrm{M}$ & Breast cancer cell line MCF-7 & $\begin{array}{l}\text { Increase } \gamma \mathrm{H}_{2} \mathrm{AX} \text {, phosphorylation of } \\
\text { ATM/ATR, ROS }\end{array}$ & Chen et al. (2005); Ren et al. (2015) \\
\hline Carnosol & $25 \mu \mathrm{M}$ & $\begin{array}{l}\text { Human breast cancer cell line } \\
\text { MDA-MB-231 }\end{array}$ & $\begin{array}{l}\text { Increase p21/NAF1 and } \\
\text { downregulate p27 }\end{array}$ & Al Dhaheri et al. (2014) \\
\hline Kaempferol & $\begin{array}{l}50 \text { or } \\
100 \mu \mathrm{M}\end{array}$ & $\begin{array}{l}\text { Colorectal cancer cell lines } \\
\text { HCT116, HCT15, and SW480 }\end{array}$ & Generated ROS and p53 signal & Choi et al. (2018) \\
\hline Ursolic acid & $10-40 \mu \mathrm{M}$ & Prostate cancer cell lines PC3 & $\begin{array}{l}\text { Increases Beclin-1/Atg5 and inhibits } \\
\text { Akt/mTOR }\end{array}$ & Shin et al. (2012) \\
\hline Triptolide & $200 \mathrm{nM}$ & $\begin{array}{l}\text { Human pancreatic cancer cell line } \\
\text { S2-013, S2-VP10, and Hs766T }\end{array}$ & Inhibits of Akt-mTOR-P70S6K & Mujumdar et al. (2010) \\
\hline
\end{tabular}

have shown that apigenin can inhibit cell growth and induce autophagy in time-and dose-dependent manners in HepG2 cells (Zhong et al., 2010). Autophagy was also found to be mediated via the inhibition of the PI3K/Akt/mTOR pathway in HepG2 cells (Yang et al., 2018). An organic sulfur compound, allicin, acts as an antitumor agent that activates autophagic cell death by inhibiting the PI3K/mTOR signaling pathway (Sak, 2012). Allicin also inhibits the expression of p53 and $\mathrm{Bcl}-2$, and upregulates the Beclin-1 signaling and AMPK/TSC2 signaling pathways (Chu et al., 2012). Anthocyanins (ACNs) present in black soybeans induce autophagy; however, their underlying mechanism have yet to be determined (Choe et al., 2012). Aspalathin is a polyphenolic dihydrochalcone C-glucoside that plays a critical role in inhibiting Dox-induced cardiotoxicity and decreasing P53 expression. Aspalatin triggered autophagy-related genes and decreased p62 by inducing the AMPK and Fox pathways (Johnson et al., 2017). Berberine is an isoquinoline alkaloid that exerts anticancer activity for autophagy induction by inhibiting the AMPK/mTOR/ULK1 pathway (Wang et al., 2016a). Celastrol is another triterpenoid that is effective against human prostate cancer. Celastrol blocks the AR signaling pathway, which induces autophagy and downregulates the expression of miR-101 (Guo et al., 2015). Cordycepin generates ROS in cancer cells and enhances p53 and LC3I/II expression, thereby modulating autophagy (Chaicharoenaudomrung et al., 2018). Cordycepin inhibits renal carcinoma in the migration of the Caki-1 cell line by reducing microRNA-21 expression and Akt phosphorylation, and increasing PTEN phosphatase levels (Yang et al., 2017). In addition, cordycepin induces autophagy via Bax activation in ovarian cancer cell lines, including SKOV-3 and OVCAR-3 (Jang et al., 2019). Curcumin has been shown to increase ROS and DNA damage in cancer cells. Further, curcumin increased the phosphorylation of ERK1/2 and p38 MAPK, inhibited Akt and P54 JNK (Masuelli et al., 2017), and eventually induced autophagy in NSLCA549 cells (Liu et al., 2018). Evodiamine, a quinolone alkaloid, mediates autophagy activation by upregulating Beclin-1 and Bax expression and downregulating
Bcl-2 (Rasul et al., 2012). Fisetin is a naturally occurring flavonoid that is reported to suppress the mTOR signaling pathway via the inhibition of Akt and activation of AMPK, and autophagic programmed cell death in prostate cancer cells (Suh et al., 2010). Similarly, genistein displayed chemopreventive and chemotherapeutic effects in cancer cells. Treating ovarian cancer cells with genistein led to a reduction in Akt phosphorylation and induced autophagy, thereby contributing to glucose uptake reduction in cancer cells (Gossner et al., 2007). Ginsenoside F2 showed anti-proliferative activity and initiated the autophagic process in breast cancer stem cells. Concurrently, ginsenoside F2 elevated Atg-7 levels, induced the formation of acidic vascular organelles, and recruited GFP-tagged LC3-II to autophagosomes (Mai et al., 2012). Hispolon, a phenolic compound isolated from Phellinus igniarius (L.) Quél., exhibited apoptotic and anti-tumor effects in cervical cancer cell lines and notably induced autophagy. Treatment with hispolon inhibited metastasis by downregulating lysosomal protease cathepsin S (CTSS) (Chen et al., 2012). Further, hispolon was found to mechanistically block the ERK pathway and enhance LC3 conversion and acidic vesicular organelle formation (Hsin et al., 2017). 3'-hydroxydaidzein ( $3^{\prime}$-ODI) is another phytochemical derivative that induces autophagy. In fact, it was found to significantly reduce a-MSH-mediated melanogenesis in melanoma cells (Kim et al., 2013). Toxicarioside $\mathrm{O}$, a natural product derived from the Antira toxicaria Lesch., showed anticancer potency through autophagy induction via the subsequent reduction of the Akt/ mTOR pathway (Huang et al., 2017). Falcarindiol (FAD), a natural polyene (Minto and Blacklock, 2008) promotes autophagy in response to ER stress (Jin et al., 2012) while a-mangostin mediates autophagic cell death via AMPK activation in human glioblastoma cells (Chao et al., 2011). The bioflavonoid, quercetin, possesses anticancer and antiinflammatory properties. In hyperactive primary effusion lymphoma (PEL), quercetin reduced the release of cytokines and inhibited PI3K/Akt/mTOR and STAT3 pathway-induced autophagy, ultimately resulting in PEL cell death (Granato 
et al., 2017). In breast cancer steam cells, rottlerin (Rott) enhanced the expression of LC3, Beclin-1, and Atg12 aggregation during autophagy. Silibinin (silybin) is a chemoprotective flavonoid that might exhibit anti-metastatic effects on renal cell carcinoma (RCC). Silibinin increased the expression of LC3-II, which not only suppressed mTOR regulation but also activated the AMPK pathway (Li et al., 2015). Sulforaphane (SFN) is a group of phytochemicals that are referred to as isothiocyanates (Uddin et al., 2020). Multiple studies have shown that autophagy in SFN-induced cell death eliminates highly resistant pancreatic carcinoma cells by releasing ROS, without exhibiting cytotoxic effects (Naumann et al., 2011; Uddin et al., 2020). Gintonin has been found to stimulate autophagic flux via the Akt/mTOR/p70S6K-mediated pathway in primary cortical astrocytes (Rahman et al., 2020b). Ursolic acid (UA), a pentacyclic triterpenoid, showed anti-proliferative effects via G1 phase arrest and induced autophagy regulation through the beclin-1 and Akt/mTOR pathways (Shin et al., 2012). Tripchlorolide is present in tripterygium. Treatment with tripchlorolide was found to attenuate the expression of the PI3K/Akt/mTOR signaling pathway (Chen et al., 2017a). Tetrandrine is a bisbenzylisoquinoline alkaloid isolated from the Chinese medicinal herb, Stephania tetrandra S. Moore. Tetrandrine plays an important role in the suppression of human hepatocellular carcinoma, inhibits the Wnt/ $\beta$-catenin pathway, and reduces MTA1 expression, which eventually causes autophagy (Zhang et al., 2018). N-desmethyldauricine is a novel inducer of autophagy that is mediated by the inhibition of Ulk-1/PERK/AMPK mTOR and causes calcium accumulation, leading to autophagic cell death (Law et al., 2017). Quinacrine displayed anticancer properties in breast cancer cells by enhancing p53 and p21 regulation and inhibiting topoisomerase activity (Mohapatra et al., 2012). The anti-proliferative activity of tangeritin initiates anticancer activity by modulating autophagy and inducing the CYP1 enzyme and CYP1A1/CYP1B1 proteins in MDA-MB-468 and MCF-7 cells (Surichan et al., 2018). Multiple studies have indicated that licochalcone A treatment activates the LC3-II signaling pathway and suppresses the $\mathrm{PI} 3 \mathrm{~K} / \mathrm{Akt} / \mathrm{mTOR}$ pathway to promote autophagy in MCF-7 cells (Xue et al., 2018). In addition, ophiopogonin B was found to induce autophagy by inhibiting the PI3K/Akt/mTOR signaling pathway (Chen et al., 2013a). Anticancer activity was also exhibited by juglanin, which is generally extracted from green husks. Juglanin-mediated treatment attenuated $\mathrm{G} 2 / \mathrm{M}$ phase arrest and induced autophagy by regulating the ROS/JNK signaling pathway in human breast cancer (Sun et al., 2017a). Cucurbitacin B (Cuc B) is another natural tetracyclic triterpene compound that is generally used as an anti-inflammatory drug (Chen et al., 2005). Treatment with Cuc B increases $\gamma \mathrm{H}_{2} \mathrm{AX}$ protein expression, promotes DNA damage through phosphorylation of ATM/ ATR, and concurrently increases the level of ROS that induces autophagy in MCF-7 cells (Ren et al., 2015).

\section{Phytochemicals in Apoptosis Signaling}

Angelica polymorpha Maxim, which contains angelicin, increases cellular cytotoxicity and induces apoptosis by decreasing the expression of anti-apoptotic proteins, including Bcl-xL, Bcl-2, and Mcl-1 in SH-SY5Y human neuroblastoma cells (Rahman et al., 2012b; Rahman et al., 2012b). As FAD-induced cell death is known to be caused by caspase-dependent modulation, FAD is suggested to have a synergistic effect on several approved cancer drugs designed to kill cancer cells ( $\mathrm{Lu}$ et al., 2017). Alisol B induces autophagy by modulating the CaMKK-AMPK-mTOR signaling pathway, calcium mobilization, and enhanced ER stress, leading to apoptotic cell death (Law et al., 2010). Luteolin is a flavonoid found in various plants and is known to play a leading role in hepatocellular carcinoma cell lines through G0/G1 phase cell cycle arrest. Studies have shown that treatment with luteolin induces apoptosis by increasing caspase- 8 expression, reducing $\mathrm{Bcl}-2$ at the mRNA level, improving the conversion of LC3B-I to LC3B-II, and decreasing the viability of SMMC-7721 cells (Cao et al., 2017). In the human carcinoma BEL-7402 cell line, oridonin-mediated apoptosis was found to be driven by the activation of caspase- 3 as well as reduced Bcl- 2 expression and Bax upregulation, which can inhibit cell growth (Zhang et al., 2006). Prolonged treatment with Rott in breast CSCs suppressed the phosphorylation of Akt and mTOR, and upregulated the phosphorylation of AMPK, eventually upregulating apoptosis (Kumar et al., 2013). Several natural plant extracts derived from Dioscorea nipponica Makino, Melandrium firmum (Sieb. \& Zucc.) Rohrb., and Saussurea lappa (Decne.) Sch. Bip. have been found to induce anti-proliferative effects and apoptotic cell death in human neuroblastoma cells (Rahman et al., 2013; Rahman et al., 2014; Rahman et al., 2015). $\gamma$-Tocotrienol, a vitamin E isomer (Ling et al., 2012), is known to target Ang$1 /$ Tie-2 and exert anti-cancer effects through the activation of AMPK signaling, leading to apoptotic cell death in human prostate cancer cell lines (Tang et al., 2019). Triptolide induced apoptosis in pancreatic cancer cells, causing the inactivation of $\mathrm{Akt} / \mathrm{mTOR} / \mathrm{p} 70 \mathrm{~S} 6 \mathrm{~K}$ and upregulation of the ERK1/2 pathway (Mujumdar et al., 2010). Kaempferol is a flavonoid compound that generates ROS and p53 signals and regulates p38 phosphorylation as well as caspase activation, thereby inducing apoptosis of colorectal cancer cells (Choi et al., 2018). Myricetin is a natural flavonoid found in various fruits and vegetables. A previous report suggested that myricetin attenuated tumor cell growth by promoting apoptotic cell death (Cao et al., 2018). Myricetin exerts pro-apoptotic and cytotoxic effects on prostate cancer cells by inhibiting P1M1 and downregulating the interaction between P1M1 and CXCR4 (Ye et al., 2018). Galangin induced apoptosis in kidney cancer cells by increasing the expression of Bax and Cyt-c and decreasing Bcl-2 expression (Zhu et al., 2018). In a human breast cancer cell line, isorhamnetin inhibited tumor growth by inducing cell cycle arrest in the S-phase and displayed strong cytotoxic effects via the ROS-dependent apoptotic pathway (Wu et al., 2018). In H522 cells, Hesperet induced apoptotic cell death by downregulating caspase-3/9, p53, and Bax expression and upregulating Fas, FADD, and caspase-8 expression (Elango et al., 2018). Cyanidin-3-glucoside (C3G) is an ACN found in fruits. $\mathrm{C} 3 \mathrm{G}$ exerts anti-inflammatory properties and induces miR-124 expression. Concurrently, miR-124 regulation downregulates STAT3 and inhibits angiogenesis induced by C3G in human 
breast cancer (Ma and Ning, 2019). Benzyl isothiocyanate (BITC) is present in cruciferous vegetables. Administering BITC to mice caused decreased phosphorylation of PI3K/Akt/FOXO1/PDK1/ mTOR/FOXO3a, which suppressed pancreatic cancer cell growth and induced apoptosis (Boreddy et al., 2011). Several studies have reported that glucosinolate-derived phenethyl isothiocyanates (PEITC) are promising anti-tumorigenic agents. In fact, PEITC-treated mice were found to exhibit reduced expression of HER2, EGFR, and STAT3, and enhanced apoptosis through the cleavage of caspase 3 and PARP (Gupta and Srivastava, 2012). NCTD inhibits c-Met and mTOR and exhibits anticancer properties (Sun et al., 2017b).

\section{Phytochemicals in Autophagic-Apoptotic Signaling}

$\beta$-Elemene is a natural chemical compound collected from different medicinal plants, such as Curcuma WenYuJin (Edris, 2009). $\beta$-Elemene exerts cytoprotective activity by converting LC3-I into LC3-II to form autolysosomes that activate autophagy and significantly reduce the in vitro growth of human breast cancer cells via apoptosis (Guan et al., 2014). Capsaicin is another naturally occurring phytochemical that exerts antitumor potency by downregulating the PI3K/Akt/ mTOR pathway. Capsaicin instigates the autophagy process by increasing the expression of the autophagy markers, LC3-II and Atg5, and enhances the degradation of p62 and Fap-1, while increasing caspase-3 activity (Lin et al., 2017a). The Morus alba L. root extract containing oxyresveratrol was previously found to accumulate ROS and induce autophagic and apoptotic cell death via the FOXO-Caspase-3 pathway in human neuroblastoma cells (Kwon et al., 2015; Rahman et al., 2017). Gingerol possesses antioxidant, anti-inflammatory, and anti-tumor properties (Shukla and Singh, 2007; Baliga et al., 2011), and inhibits colon cancer cell proliferation by activating the caspasedependent pathway and concurrently cleaving PARP, which induces autophagy (Radhakrishnan et al., 2014). Concurrent treatment with honokiol (Hono) and magnolol (Mag) decreased the expression of cyclin A, D1, and cyclindependent kinase, which arrests cell cycle progression and reduces p-PI3K, p-Akt, and Ki67 expression in U87MG and LN229 human glioma cells. Both Hono-and Mag-mediated treatments exert synergistic anti-tumor effects by inhibiting cell proliferation. Accordingly, they induce autophagy and apoptosis in human GMB cells (Cheng et al., 2016). 6-Shogaol disrupts the Akt/mTOR mediated signaling pathway; blocking of Akt is beneficial to apoptotic cell death. 6-Shogaol induces autophagy through the inhibition of Akt overexpression and exhibits anticancer activity against non-small cell lung cancer (Hung et al., 2009). Thymoquinone (TQ), a major component of black cumin, exhibits potent cytotoxic effects in several cancer cell lines. In SASVO3 cells, TQ was found to mediate cell death caused by the enhancement of Bax expression and increase autophagic vacuoles and LC3-II protein expression following apoptosis and autophagy (Chu et al., 2014). In our previously published study, we revealed that the gap-junction inhibitor, $18 \alpha-$ Glycyrrhetinic acid (18-GA), induces apoptosis and autophagy.
18-GA-induced autophagy has been shown to induce Atg5, Atg7, and LC3II accumulation through p62 degradation (Rahman et al., 2016b). 18-GA was also found to destabilize the Bcl-2/Beclin-1 interaction and the cleavage of Beclin-1, ultimately highlighting the occurrence of mitochondrial-mediated apoptosis in SH-SY5Y cells (Figure 4). 18-GA is also known to activate several MAPKs and arrest the cell cycle, which leads to the activation of apoptosis. 18-GA may thus be used as a therapeutic target for the apoptosisautophagy pathway in neuroblastoma.

Delphinidin is an anthocyanidin monomer with strong antioxidative characteristics. In HER-2 positive breast cancer cells, delphinidin enhances apoptosis and autophagy by suppressing mTOR and activating the AMPK signaling pathway (Chen et al., 2018). Emerging evidence has shown that epicatechin-3-Ogallate (EGCG) promotes autophagy and apoptosis in different cancer lines (Siddiqui et al., 2011; Grube et al., 2018; Stadlbauer et al., 2018). Previously, OxyR was found to simultaneously activate apoptosis and autophagy in NB. OxyR also reduces $\mathrm{PI} 3 \mathrm{~K} / \mathrm{Akt} / \mathrm{mTOR}$ signaling and enhances cytotoxicity by increasing autophagy levels (Figure 5) (Rahman et al., 2017). OxyR-induced cell death was found to occur independent of apoptosis induction due to alterations in the levels of PI3K/Akt/ mTOR and p38 MAPK activity in SH-SY5Y cells.

Saikosaponin-d is reported to induce intracellular calcium accumulation and autophagy by activating the CaMKK $\beta$ AMPK-mTOR pathway. Nonetheless, ER stress and UPR activation by saikosaponin-d have been demonstrated to trigger apoptosis and autophagic cell death (Wong et al., 2013). Isoliquiritigenin (ISL) hinders the viability of ovarian cancer cell lines (OVCAR5) and the ES-2 model. ISL also induced autophagy in OVCAR5 via cell cycle arrest at the G2/ $M$ phase, cleaved caspase-3, and increased LC3B-II and Beclin-1 expression (Chen et al., 2017b). Guttiferone K (GUTK) isolated from garcinia yunnanensis $\mathrm{Hu}$ (Xu et al., 2008) was found to reduce Akt phosphorylation and inhibit the mTOR pathway. GUTK also enhanced ROS and triggered the phosphorylation of JNK in EBSS, which induced autophagy and apoptosis under nutrient-deficient conditions (Wu et al., 2015).

\section{PHYTOCHEMICALS MODULATE AUTOPHAGY-APOPTOSIS THROUGH ROS SIGNALING}

ROS, such as $\mathrm{O}_{2}{ }^{\bullet-}, \mathrm{H}_{2} \mathrm{O}_{2}$, and ${ }^{\bullet} \mathrm{OH}$, are generated as metabolic by-products by biological systems; such generation may trigger detrimental as well as useful health outcomes (Covarrubias et al., 2008; Sena and Chandel, 2012). An optimum level of ROS is required for different biological processes, such as cell signaling, activation of proteins, immune function and transcriptional factors, and the regulation of apoptosis and differentiation (Rajendran et al., 2014). However, overproduction of ROS may have damaging effects on various proteins, lipids, and nucleic acids (Wu et al., 2013). Thus, an imbalance in ROS levels may be the cause of several diseases, such as cancer. Cellular ROS levels are also critical for cancer progression (Aggarwal et al., 2019). ROS-mediated DNA damage may play 


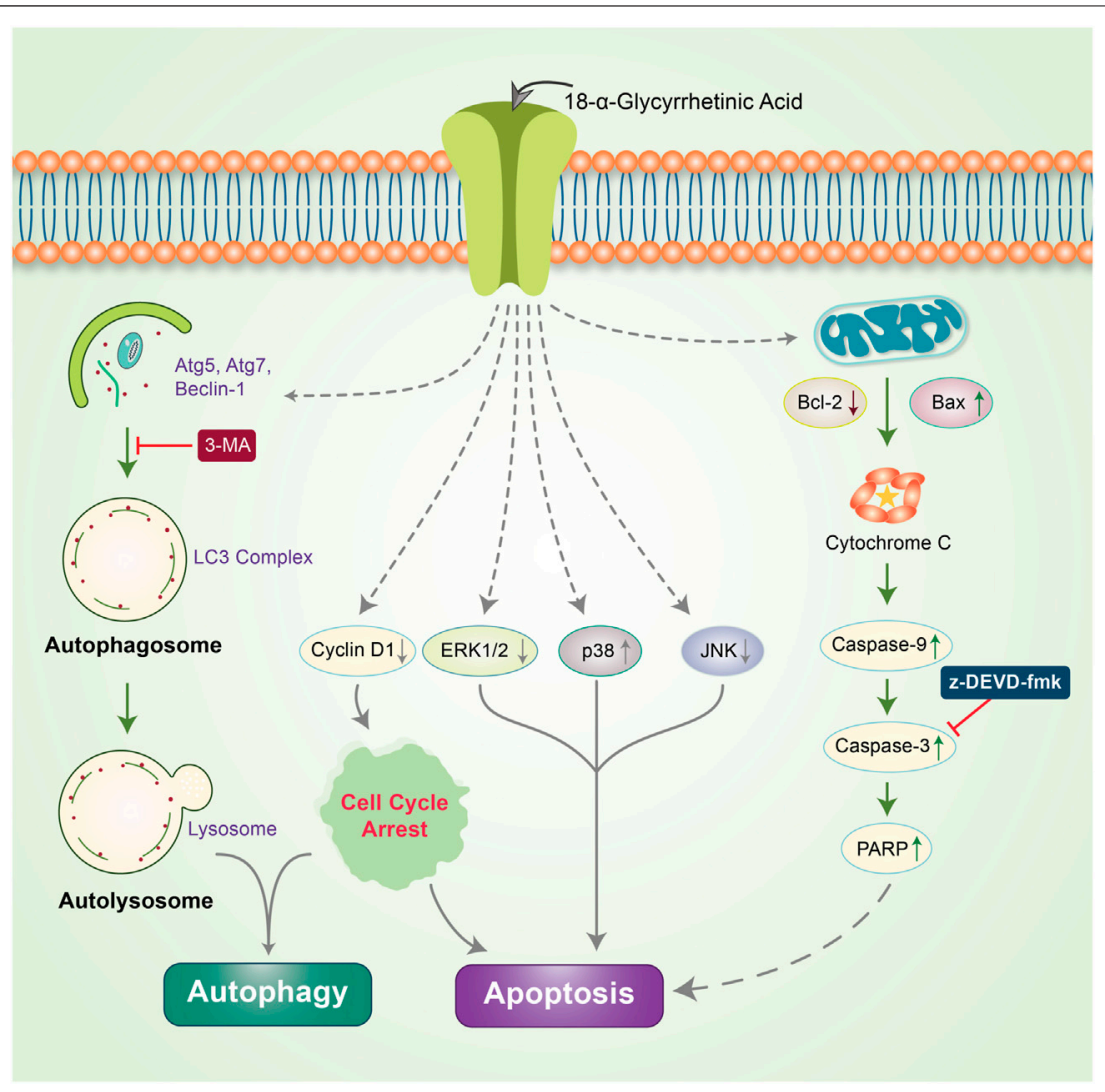

FIGURE 4 | Anticancer effects of 18-GA in autophagy-apoptosis modulation in neuroblastoma cells. 18-GA encouraged caspase-induced apoptosis by depolarizing the mitochondria membrane potential (MMP). 18-GA also induced early autophagy through Atg5 and Atg7 activation and converted LC3I to LC3II. The autophagy inhibitor, 3-MA, inhibited 18-GA-mediated autophagy. Nonetheless, 18-GA caused the downregulation of ERK1/2, JNK, and cyclinD1 protein and the upregulation of p38 MAPK, which activated apoptosis in neuroblastoma cancer.

a critical role in the initiation and progression of carcinogenesis. Reversible DNA damage may allow an internal repair system to normalize the adverse effects of ROS. However, irreversible damage may not permit the proper functioning of the repair system. As a result, the cells undergo apoptosis, which has a considerable effect in cancer therapy (Aggarwal et al., 2019).

As antioxidant phytochemicals can inhibit the growth of different cancer cells, they could serve as good candidates for anticancer therapy (Barrajón-Catalán et al., 2010; Sak, 2014). Depending on the concentration, exposure time, and ability of oxidative stress-inducing compounds, ROS signaling may act as an autophagic activator or apoptotic initiator in target cancer cells (Chirumbolo et al., 2018). EGCG is the most abundant polyphenol in green tea. EGCG has been found to induce apoptosis and autophagy in human mesothelioma cell death through prompting ROS (Satoh et al., 2013). Ha et al. represented that ROS generation is important in quercetin-meiated apoptotic cell death in Jurkat $\mathrm{T}$ cells has been targeted via BCL-XL antiapoptotic action protein (Ha et al., 2019). Epicatechins as shown to modulate autophagy and endoplasmic reticulum (ER) stress-induced apoptostic cell death of human various diseases (Zhang et al., 2020a). Gallic acid, 3,4,5trihydroxy-benzoic acid found in red wine and grapes, acts as an auto-oxidation in addition to produce $\mathrm{H}_{2} \mathrm{O}_{2}$ and $\mathrm{O}_{2}^{-}$lead to intrinsic mitochondria-mediated apoptosis in prostate cancer cells (Russell Jr et al., 2012). Gallic acid prevents lung cancer cell growth via elevating ROS level as well as GSH depleting (Wang et al., 2016b). Gallic acid additionally encourages apoptosis through ROS-mediated activation of JNK pathways (Chen et al., 2013b). Oxidation of catechin-derived quinone has also been observed to result in anti-tumor activities in several human cancer cells through apoptotic as well as autophagic cell death via modulating ROS (Saibu et al., 2014; Lee et al., 2017). Thus, activation of oxidative stress signaling may not always be associated with unexpected side effects. A high dose of EGCG exerts pro-oxidant effects, which ultimately leads to autophagy activation and increased antitumor activity (Yang et al., 1998; Tsai et al., 2018; Bimonte et al., 2019). EGCG induces apoptosis in cancer cells through different mechanisms, including the suppression of PI3K/Akt signaling (Liu et al., 2016), reduction in mitochondrial membrane potential (Li et al., 2009) and expression of anti-apoptotic proteins, including Bcl-2, xIAP, and Bcl-xl (Wu et al., 2009). Previously, quercetin was found to promote ROS-stimulated apoptosis and autophagy in different cancers (Choi et al., 2008; Bi et al., 2016) by activating caspase- 3 and inhibiting anti-apoptotic proteins, such as $\mathrm{Bcl}-2$ and $\mathrm{Bcl}-\mathrm{xl}$. Additionally, quercetin reduces apoptosis in addition to decrease intervertebral disc degeneration through SIRT-mediated autophagy induction (Wang et al., 2020). In 


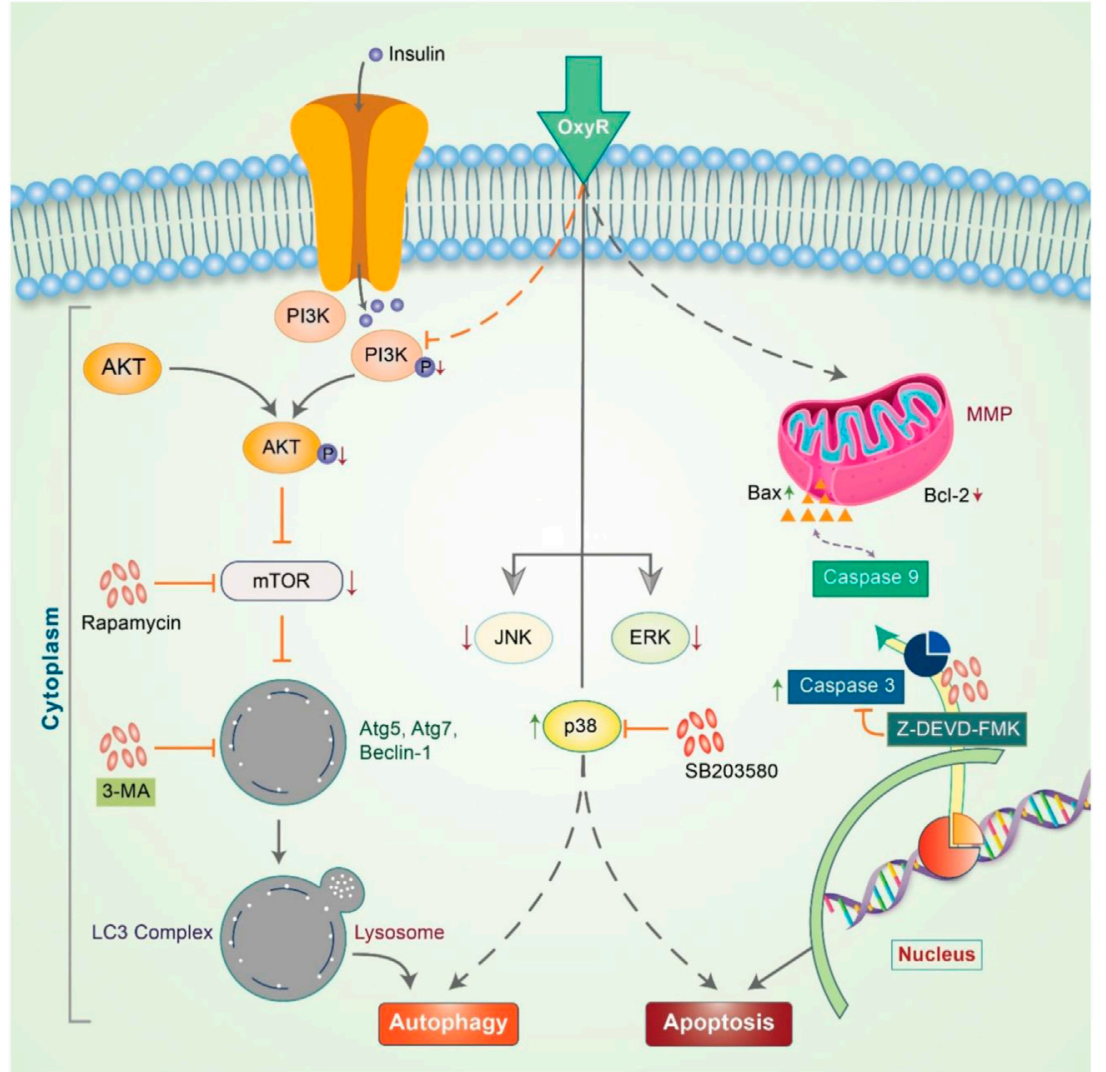

FIGURE 5 | Oxyresveratrol controls the autophagy-apoptosis signal to modulate neuroblastoma cells. OxyR activates PI3K/Akt/mTOR and the inhibition of mTOR by rapamycin blocks autophagy, indicating an mTOR-dependent autophagic pathway. OxyR led to arrest at the G2/M phase of the cell cycle and activated mitochondria-mediated caspase-3 dependent apoptosis. OxyR was also revealed to increase Bax/Bcl-2 ratio without generating ROS or activating p53. When the p38 inhibitor, SB203580, was applied, OxyR was found to activate autophagy-apoptosis signaling in neuroblastoma cells.

cancer cells, curcumin enhances TRAIL-induced apoptosis via ROSmediated DR5 upregulation (Jung et al., 2005) and activates autophagy through the ROS-ERK1/2-p38 MAPK signaling pathway (Lee et al., 2011). Resveratrol has also been demonstrated to possess beneficial effects (Moni et al., 2018) it promotes apoptosis via ROS-dependent caspase activation (Shankar et al., 2007) and Bax/caspase-3 (Whitlock and Baek, 2012) and induces apoptosis associated with mitochondrial dysfunction in cancer cells (Lin et al., 2012). As depicted in Figure 6, phytochemicals are important modulators of cancer cell control owing to the autophagy-apoptosis pathways.

\section{THERAPEUTIC TARGETS OF PHYTOCHEMICALS IN AUTOPHAGY-APOPTOSIS MODULATION FOR CANCER PREVENTION}

Phytochemicals and naturally occurring compounds are wellknown to ameliorate several human diseases owing to their pharmacological activities (Hannan et al., 2020; Rahman et al., 2020b). The most well-known anticancer agents, including taxol, resveratrol, vincristine, quercetin, vinblastine, tetrandrine, and arteannuin, modulate the autophagy-apoptosis pathway (Sun et al., 2019). Polyphenolic compounds and alkaloids are particularly dominant among all other cancer therapeutics (Newman and Cragg, 2016). Polyphenols play a greater role in apoptotic, autophagic, and cytostatic activities owing to their antioxidant properties, thereby serving as preventative cancer therapies (Focaccetti et al., 2019). Polyphenols can easily bind to cell membranes and trigger numerous signaling pathways, including caspases, epidermal growth factor (EGF), Bcl-2 family proteins, mitogen-activated protein kinase (MAPK), microRNAs (miRNAs), nuclear factor (NF)- $\kappa$ B phosphatidylinositol-3-kinase PI3K/Akt/mTOR, and epidermal growth factor receptor (EGFR) (Sun et al., 2019). MicroRNAs (miRNAs) have also been demonstrated to regulate gene expression and are targeted as novel therapeutic approaches to control cancer; phytochemicals, such as resveratrol, silibinin, curcumin, genistein, and EGCG can be employed as apoptotic inducers, autophagy modulators, and cell cycle inhibitors (Lancon et al., 2012; Estrela et al., 2017; Jahanafrooz et al., 2018). miRNAs have been predicted to be critical for modulating cancer cell differentiation, invasion, proliferation, autophagy, and apoptosis via the regulation of oncogenic gene 


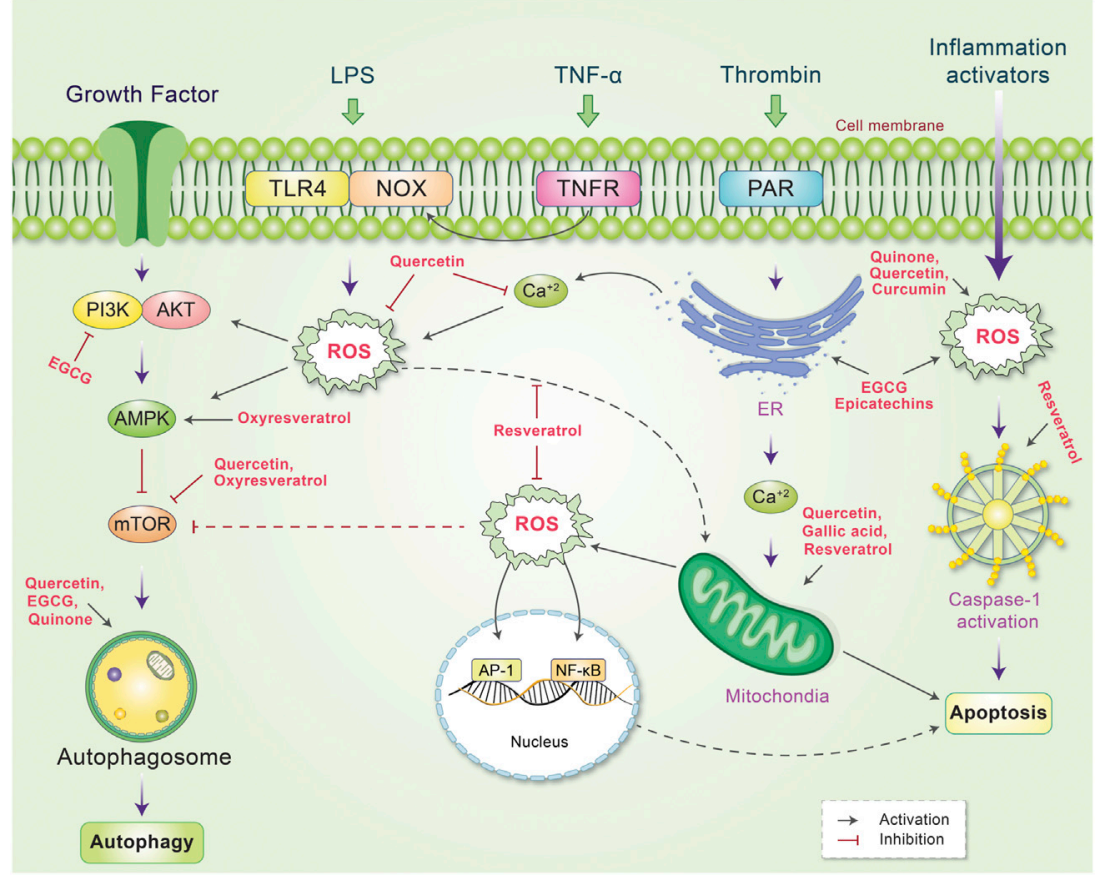

FIGURE 6 | Schematic representation of the mechanism of action of phytochemicals and reactive oxygen species (ROS), which lead to the control of several signaling pathways. ROS is produced by several internal and external stimuli. Extranally, ROS is activated through growth factors, LPS, TNF-a, thrombin, and inflammation. Different phytochemicals have been found to scavenge or decrease cellular ROS level by inhibiting or stimulating their action. Internally, phytochemicals inhibit PI3K or mTOR, which activates autophagy and reduces ROS production. Some phytochemicals have also been found to activate mitochrondrial ROS production while other phytochemicals scavenge ROS and protect against DNA damage. ROS production mediated by ER and inflammation activators is also reduced by phytochemicals, which modulate the autophagy-apoptosis pathways.

expression (Karius et al., 2012). Further, the MAPK and PI3K/ Akt/mTOR signaling pathways have been shown to activate NF$\kappa \mathrm{B}$ in numerous cancer cell lines by modulating several phytochemicals in the autophagy-apoptosis pathway (Chao et al., 2017). Matrix metalloproteinase (MMP)-2 and MMP-9 modulate the autophagy-apoptosis pathway and control cancer through the action of different polyphenols (Balli et al., 2016).

Based on scientific evidence, phytochemicals present substantial anticancer potential for bench to bedside drug development. In fact, preclinical screening models can be used to assess their preliminary toxicity, safety, pharmacokinetics, and efficacy, which may serve as useful information for clinical trials (Zhang et al., 2020b). The preclinical efficacy of several phytochemicals, including ursolic acid, baicalein, genistein, 6Shogaol, apigenin, thymoquinone, allicin, dicumarol, epigallocatechin, alpinumisoflavone, sulforaphane, curcumin, emodin, withaferin A, resveratrol, gingerol, physapubescin $\mathrm{B}$, nimbolide, licochalcone A, glycyrrhizin, and hispidulin, has been demonstrated using numerous animal models (Choudhari et al., 2020). Despite several assessments of phytochemicals against cancer in the clinical trial setting, most trials continue to be in the early stage as numerous anti-cancer chemicals are currently being investigated. The most important phytochemicals under clinical trial investigation for various cancers include sulforaphane, resveratrol, lycopene, epigallocatechin, curcumin, and berberine; these phytochemicals aim to target the autophagy-apoptosis pathway (Choudhari et al., 2020).

\section{LIMITATIONS OF TARGETING THE AUTOPHAGY-APOPTOSIS CROSSTALK USING PHYTOCHEMICALS IN ANTICANCER DRUG DEVELOPMENT}

Increasing evidence suggests that phytochemicals could exhibit anticancer effects by modulating various signaling pathways, such as autophagy and apoptosis (Figure 3). These two significant cellular pathways are largely responsible for determining the fate of cancerous cells (Su et al., 2013). However, such finding is mainly based on in vitro and preclinical in vivo investigations that may not necessarily guarantee clinical outcomes. Moreover, many phytochemicals target multiple signaling pathways that may be shared among multiple cellular systems. These multitargeted effects of phytochemicals may generate positive outcomes, but can also lead to unanticipated effects, thereby challenging the development of phytochemical-based anticancer drugs. Although many phytochemicals are not specific in their action and exert multitarget effects, it is uncertain whether their anticancer effects are autophagy-dependent or merely a response to mitigate the adverse conditions that support the survival of 
cells in the tumor microenvironment (Patra et al., 2020). Although autophagy and apoptosis are two critical cellular pathways in cancer biology, their specific roles remain unclear. However, because autophagy plays a critical role in cellular protein homeostasis and other quality control systems, modulating this crucial pathway may hamper cellular physiology. As autophagy is considered to be a double-edge sword, targeting this pathway may result in unprecedented outcomes.

\section{CONCLUSION AND FUTURE PERSPECTIVES}

As the incidence of cancer increases on a daily basis, new strategies are being discovered to ensure this fatal disease is managed therapeutically. The major challenge in developing target-specific anticancer drugs is inextricably linked to the complexity of cancer pathobiology. Autophagy and apoptosis are two vital cellular pathways involved in cancer development and regulation. In addition, crosstalk is known to occur across signaling pathways, including those associated with autophagy and apoptosis. Many cancer types are becoming resistant to chemotherapy due to defects in signaling pathways, particularly apoptosis. As an alternative cell fate mechanism, autophagy could be explored for the development of targetspecific anticancer drugs. Further investigations, both in vitro and in vivo, are however necessary to better understand cancer pathobiology, which will enable the full potential of autophagyapoptosis-targeted drug design to be exploited.

Scientists have always been interested in the use of plant products and their derivatives as successful sources of anticancer therapeutics. In fact, there is increasing evidence suggesting the emerging anticancer potential of phytochemicals that modulate several signaling pathways, including autophagy and apoptosis. The anticancer effects of phytochemicals have been observed to be selective and specific to cancer cells, and involve the modulation of autophagy and apoptosis. As a result, many phytochemicals are promising sources of anticancer drugs. The most notable phytochemicals that have exerted their anticancer potential in vitro and in vivo through modulating the autophagy-apoptosis pathway (i.e., sulforaphane, resveratrol, lycopene, epigallocatechin, curcumin, and berberine) are currently being investigated in clinical trials for different cancer types.

Because autophagy plays a context-dependent role in cancer patients, targeting this crucial cellular pathway may not always be beneficial. Furthermore, several phytochemicals target multiple signaling pathways that may be shared among multiple cellular systems, thereby posing a challenge to the development of phytochemical-based anticancer drugs. This issue could however be resolved through in vitro and in vivo studies on phytochemical-mediated autophagy-apoptosis modulation. In addition, an integrated system pharmacology and computational approach could be employed to better understand the anticancer effects of phytochemicals. As the clinical application of phytochemicals is limited by their poor bioavailability, improvements can be achieved by employing nanotechnology-based drug delivery. Based on the highlights in this review, the potential as well as the challenges of phytochemical-mediated targeting of autophagy and apoptosis could unravel new approaches and strategies for the development of novel anticancer therapeutics to treat several cancer types.

Eventually, upcoming challenges as well as possible perspectives have been demonstrated in the hope of improving anticancer effectiveness in addition to accelerate the translational improvement of precise nanomedicine or nanotechnology for targeted cancer therapy based on autophagy-apoptosis pathway. Nanoparticle-based drug delivery systems (NDDSs) have been comprehensively used in the diagnosis, therapy, as well as cancer imaging because of their features of extraordinary cancertargeting efficiency and low toxic properties. Nevertheless, because of the problems of poor patient prognosis, high variability, as well as multidrug resistance (MDR), NDDSs have currently been challenged remarkable experiments. Indeed, combined targets of nanoscience along with naturally occurring bioactive compounds are very attractive as well as developing rapidly in recent times in combination with conventional drugs for improving clinical outcomes. Therefore, it would be urgently required to necessary with designing novel treatment approaches to investigate in-depth the early diagnosis and pathogenesis of cancer thereby targeting phytochemicals through autophagy-apoptosis pathway.

\section{AUTHOR CONTRIBUTIONS}

Idea and conceptualization by MAR. Figures are drawing by MHR. Writing and original draft preparation by MAH, RD, RI, MJU, AAMS, and MHR. Visualization and supervision by HR. All authors have read and agreed to the published version of the manuscript.

\section{FUNDING}

This work was supported by NRF Research Program (2016M3C7A1913845) and the Korea Research Fellowship (KRF) Program (M.A.R. 2016H1D3A1908615; M.A.H. 2018H1D3A1A01074712 to.; R.I. 2020H1D3A1A04104782), and additionally supported by (M.J.U. 2020R1I1A1A01072879 and 2020H1D3A2A02110924) funded by the Ministry of Science and ICT, Republic of Korea, and the KIST Institutional Programs (2E30962). 


\section{REFERENCES}

Aggarwal, V., Tuli, H. S., Varol, A., Thakral, F., Yerer, M. B., Sak, K., et al. (2019). Role of reactive oxygen species in cancer progression: molecular mechanisms and recent advancements. Biomolecules. 9, 735. doi:10.3390/biom9110735

Al Dhaheri, Y., Attoub, S., Ramadan, G., Arafat, K., Bajbouj, K., Karuvantevida, N., et al. (2014). Carnosol induces ROS-mediated beclin1-independent autophagy and apoptosis in triple negative breast cancer. PLoS One. 9, e109630. doi:10. 1371/journal.pone.0109630

Alers, S., Loffler, A. S., Wesselborg, S., and Stork, B. (2012). Role of AMPK-mTORulk1/2 in the regulation of autophagy: cross talk, shortcuts, and feedbacks. Mol. Cell Biol. 32, 2-11. doi:10.1128/Mcb.06159-11

Alfarouk, K. O., Stock, C.-M., Taylor, S., Walsh, M., Muddathir, A. K., Verduzco, D., et al. (2015). Resistance to cancer chemotherapy: failure in drug response from ADME to P-gp. Cancer Cel Int. 15, 71. doi:10.1186/s12935-015-0221-1

Aung, T. N., Qu, Z. P., Kortschak, R. D., and Adelson, D. L. (2017). Understanding the effectiveness of natural compound mixtures in cancer through their molecular mode of action. Int. J. Mol. Sci. 18, 656. doi:10.3390/ijms18030656

Ávalos, Y., Canales, J., Bravo-Sagua, R., Criollo, A., Lavandero, S., and Quest, A. F. G. (2014). Tumor suppression and promotion by autophagy. Biomed. Res. Int. 2014, 1. doi:10.1155/2014/603980

Baliga, M. S., Haniadka, R., Pereira, M. M., D’Souza, J. J., Pallaty, P. L., Bhat, H. P., et al. (2011). Update on the chemopreventive effects of ginger and its phytochemicals. Crit. Rev. Food Sci. Nutr. 51, 499-523. doi:10.1080/ 10408391003698669

Balli, U., Cetinkaya, B. O., Keles, G. C., Keles, Z. P., Guler, S., Sogut, M. U., et al. (2016). Assessment of MMP-1, MMP-8 and TIMP-2 in experimental periodontitis treated with kaempferol. J. Periodontal Implan. 46, 84-95. doi:10.5051/jpis.2016.46.2.84

Barrajón-Catalán, E., Fernández-Arroyo, S., Saura, D., Guillén, E., FernándezGutiérrez, A., Segura-Carretero, A., et al. (2010). Cistaceae aqueous extracts containing ellagitannins show antioxidant and antimicrobial capacity, and cytotoxic activity against human cancer cells. Food Chem. Toxicol. 48, 2273-2282. doi:10.1016/j.fct.2010.05.060

Bezerra, D. P., Pessoa, C., Moraes, M. O., Alencar, N. M., Mesquita, R. O., Lima, M. W., et al. (2008). In vivo growth inhibition of sarcoma 180 by piperlonguminine, an alkaloid amide from the Piper species. J Appl Toxicol. 28, 599-607. doi:10. 1002/jat.1311

Bhatia, K., Bhumika, and Das, A. (2020). Combinatorial drug therapy in cancer new insights. Life Sci. 258, 118134. doi:10.1016/j.lfs.2020.118134

Bi, Y., Shen, C., Li, C., Liu, Y., Gao, D., Shi, C., et al. (2016). Inhibition of autophagy induced by quercetin at a late stage enhances cytotoxic effects on glioma cells. Tumour Biol. 37, 3549-3560. doi:10.1007/s13277-015-4125-4

Bimonte, S., Albino, V., Piccirillo, M., Nasto, A., Molino, C., Palaia, R., et al. (2019). Epigallocatechin-3-gallate in the prevention and treatment of hepatocellular carcinoma: experimental findings and translational perspectives. Drug Des. Dev. Ther. 13, 611-621. doi:10.2147/DDDT.S180079

Boreddy, S. R., Pramanik, K. C., and Srivastava, S. K. (2011). Pancreatic tumor suppression by benzyl isothiocyanate is associated with inhibition of PI3K/ AKT/FOXO pathway. Clin Cancer Res. 17, 1784-1795. doi:10.1158/1078-0432. ccr-10-1891

Cao, Z., Zhang, H., Cai, X., Fang, W., Chai, D., Wen, Y., et al. (2017). Luteolin promotes cell apoptosis by inducing autophagy in hepatocellular carcinoma, cellular physiology and biochemistry. Int. J. Exp. Cell. Physiol. Biochem. Pharmacol. 43, 1803-1812. doi:10.1159/000484066

Cao, J., Chen, H., Lu, W., Wu, Y., Wu, X., Xia, D., et al. (2018). Myricetin induces protective autophagy by inhibiting the phosphorylation of mTOR in HepG2 cells, anatomical record (hoboken, N. Anat Rec (Hoboken). 301, 786-795. doi:10.1002/ar.23754

Chaicharoenaudomrung, N., Jaroonwitchawan, T., and Noisa, P. (2018). Cordycepin induces apoptotic cell death of human brain cancer through the modulation of autophagy. Toxicol. Vitro. 46, 113-121. doi:10.1016/j.tiv.2017.10.002

Chao, A. C., Hsu, Y. L., Liu, C. K., and Kuo, P. L. (2011). a-Mangostin, a dietary xanthone, induces autophagic cell death by activating the AMP-activated protein kinase pathway in glioblastoma cells. J. Agric. Food Chem. 59, 2086-2096. doi:10.1021/jf1042757
Chao, W., Deng, J. S., Li, P. Y., Liang, Y. C., and Huang, G. J. (2017). 3,4Dihydroxybenzalactone suppresses human non-small cell lung carcinoma cells metastasis via suppression of epithelial to mesenchymal transition, ROSmediated PI3K/AKT/MAPK/MMP and NF kappa B signaling pathways. Molecules. 22, 537. doi:10.3390/molecules22040537

Chen, J. C., Chiu, M. H., Nie, R. L., Cordell, G. A., and Qiu, S. X. (2005). Cucurbitacins and cucurbitane glycosides: structures and biological activities. Nat. Prod. Rep. 22, 386-399. doi:10.1039/b418841c

Chen, K.-L., Chang, W.-S. W., Cheung, C. H. A., Lin, C.-C., Huang, C.-C., Yang, Y.N., et al. (2012). Targeting cathepsin $S$ induces tumor cell autophagy via the EGFR-ERK signaling pathway. Cancer Lett. 317, 89-98. doi:10.1016/j.canlet. 2011.11.015

Chen, C. Y., Chen, K. C., Yang, T. Y., Liu, H. C., and Hsu, S. L. (2013a). Gallic acid induces a reactive oxygen species-provoked c-jun NH2-terminal kinasedependent apoptosis in lung fibroblasts. Evid. Based Complement. Alternat Med. 2013, 613950. doi:10.1155/2013/613950

Chen, M., Du, Y., Qui, M., Wang, M., Chen, K., Huang, Z., et al. (2013b). Ophiopogonin B-induced autophagy in non-small cell lung cancer cells via inhibition of the PI3K/Akt signaling pathway. Oncol. Rep. 29, 430-436. doi:10. 3892/or.2012.2131

Chen, H. Y., Huang, T. C., Shieh, T. M., Wu, C. H., Lin, L. C., and Hsia, S. M. (2017a). Isoliquiritigenin induces autophagy and inhibits ovarian cancer cell growth. Int. J. Mol. Sci. 18, 2025. doi:10.3390/ijms18102025

Chen, L. M., Song, T. J., Xiao, J. H., Huang, Z. H., Li, Y., and Lin, T. Y. (2017b). Tripchlorolide induces autophagy in lung cancer cells by inhibiting the PI3K/ AKT/mTOR pathway and improves cisplatin sensitivity in A549/DDP cells. Oncotarget. 8, 63911-63922. doi:10.18632/oncotarget.19201

Chen, J., Zhu, Y., Zhang, W., Peng, X., Zhou, J., Li, F., et al. (2018). Delphinidin induced protective autophagy via mTOR pathway suppression and AMPK pathway activation in HER-2 positive breast cancer cells. BMC Cancer. 18, 342. doi:10.1186/s12885-018-4231-y

Cheng, Y. C., Hueng, D. Y., Huang, H. Y., Chen, J. Y., and Chen, Y. (2016). Magnolol and honokiol exert a synergistic anti-tumor effect through autophagy and apoptosis in human glioblastomas. Oncotarget. 7, 29116-29130. doi:10. 18632/oncotarget.8674

Chirumbolo, S., Bjørklund, G., Lysiuk, R., Vella, A., Lenchyk, L., and Upyr, T. (2018). Targeting cancer with phytochemicals via their fine tuning of the cell survival signaling pathways. Int. J. Mol. Sci. 19. doi:10.3390/ijms19113568

Choe, Y.-J., Ha, T. J., Ko, K.-W., Lee, S.-Y., Shin, S. J., and Kim, H.-S. (2012). Anthocyanins in the black soybean (Glycine max L.) protect U2OS cells from apoptosis by inducing autophagy via the activation of adenosyl monophosphate-dependent protein kinase. Oncol. Rep. 28, 2049-2056. doi:10.3892/or.2012.2034

Choi, E. J., Bae, S. M., and Ahn, W. S. (2008). Antiproliferative effects of quercetin through cell cycle arrest and apoptosis in human breast cancer MDA-MB-453 cells. Arch. Pharm. Res. 31, 1281-1285. doi:10.1007/s12272-001-2107-0

Choi, A. M. K., Ryter, S. W., and Levine, B. (2013). Autophagy in human health and disease. N. Engl. J. Med. 368, 651-662. doi:10.1056/NEJMra1205406

Choi, J. B., Kim, J. H., Lee, H., Pak, J. N., Shim, B. S., and Kim, S. H. (2018). Reactive oxygen species and p53 mediated activation of p38 and caspases is critically involved in kaempferol induced apoptosis in colorectal cancer cells. J. Agric. Food Chem. 66, 9960-9967. doi:10.1021/acs.jafc.8b02656

Choudhari, A. S., Mandave, P. C., Deshpande, M., Ranjekar, P., and Prakash, O. (2020). Phytochemicals in cancer treatment: from preclinical studies to clinical practice. Front. Pharmacol. 10, 1614. doi:10.3389/fphar.2019.01614

Chu, Y.-L., Ho, C.-T., Chung, J.-G., Rajasekaran, R., and Sheen, L.-Y. (2012). Allicin induces p53-mediated autophagy in hep G2 human liver cancer cells. J. Agric. Food Chem. 60, 8363-8371. doi:10.1021/jf301298y

Chu, S. C., Hsieh, Y. S., Yu, C. C., Lai, Y. Y., and Chen, P. N. (2014). Thymoquinone induces cell death in human squamous carcinoma cells via caspase activationdependent apoptosis and LC3-II activation-dependent autophagy. PLoS One. 9, e101579. doi:10.1371/journal.pone.0101579

Comel, A., Sorrentino, G., Capaci, V., and Del Sal, G. (2014). The cytoplasmic side of p53's oncosuppressive activities. FEBS Lett. 588, 2600-2609. doi:10.1016/j. febslet.2014.04.015

Covarrubias, L., Hernández-García, D., Schnabel, D., Salas-Vidal, E., and CastroObregón, S. (2008). Function of reactive oxygen species during animal 
development: passive or active? Developmental Biol. 320, 1-11. doi:10.1016/j. ydbio.2008.04.041

Delmas, D., Rébé, C., Lacour, S., Filomenko, R., Athias, A., Gambert, P., et al. (2003). Resveratrol-induced apoptosis is associated with Fas redistribution in the rafts and the formation of a death-inducing signaling complex in colon cancer cells. J. Biol. Chem. 278, 41482-41490. doi:10.1074/jbc.M304896200

Deng, S., Shanmugam, M. K., Kumar, A. P., Yap, C. T., Sethi, G., and Bishayee, A. (2019). Targeting autophagy using natural compounds for cancer prevention and therapy. Cancer. 125, 1228-1246. doi:10.1002/cncr.31978

Edris, A. E. (2009). Anti-cancer properties of Nigella spp. essential oils and their major constituents, thymoquinone and beta-elemene. Curr. Clin. Pharmacol. 4, 43-46. doi:10.2174/157488409787236137

Elango, R., Athinarayanan, J., Subbarayan, V. P., Lei, D. K. Y., and Alshatwi, A. A. (2018). Hesperetin induces an apoptosis-triggered extrinsic pathway and a p53independent pathway in human lung cancer H522 cells. J. Asian Nat. Prod. Res. 20, 559-569. doi:10.1080/10286020.2017.1327949

Elmore, S. (2007). Apoptosis: a review of programmed cell death. Toxicol. Pathol. 35, 495-516. doi:10.1080/01926230701320337

Estrela, J. M., Mena, S., Obrador, E., Benlloch, M., Castellano, G., Salvador, R., et al. (2017). Polyphenolic phytochemicals in cancer prevention and therapy: bioavailability versus bioefficacy. J. Med. Chem. 60, 9413-9436. doi:10.1021/ acs.jmedchem.6b01026

Filomeni, G., De Zio, D., and Cecconi, F. (2015). Oxidative stress and autophagy: the clash between damage and metabolic needs. Cell Death Differ. 22, 377-388. doi:10.1038/cdd.2014.150

Focaccetti, C., Izzi, V., Benvenuto, M., Fazi, S., Ciuffa, S., Giganti, M. G., et al. (2019). Polyphenols as immunomodulatory compounds in the tumor microenvironment: friends or foes? Int. J. Mol. Sci. 20, 1714. doi:10.3390/ ijms20071714

Frieboes, H. B., Huang, J. S., Yin, W. C., and McNally, L. R. (2014). Chloroquinemediated cell death in metastatic pancreatic adenocarcinoma through inhibition of autophagy. JOP. 15, 189-197. doi:10.6092/1590-8577/1900

Ghavami, S., Kerkhoff, C., Los, M., Hashemi, M., Sorg, C., and Karami-Tehrani, F. (2004). Mechanism of apoptosis induced by S100A8/A9 in colon cancer cell lines: the role of ROS and the effect of metal ions. J. Leukoc. Biol. 76, 169-175. doi:10.1189/jlb.0903435

Ghobrial, I. M., Witzig, T. E., and Adjei, A. A. (2005). Targeting apoptosis pathways in cancer therapy. CA Cancer J Clin. 55, 178-194. doi:10.3322/canjclin.55.3.178

Goldar, S., Khaniani, M. S., Derakhshan, S. M., and Baradaran, B. (2015). Molecular mechanisms of apoptosis and roles in cancer development and treatment. Asian Pac. J. Cancer Prev. 16, 2129-2144. doi:10.7314/apjcp.2015.16.6.2129

Goldsmith, J., Levine, B., and Debnath, J. (2014). Autophagy and cancer metabolism. Method Enzymol. 542, 25-57. doi:10.1016/B978-0-12-416618-9. $00002-9$

Gossner, G., Choi, M., Tan, L., Fogoros, S., Griffith, K., Kuenker, M., et al. (2007). Genistein-induced apoptosis and autophagocytosis in ovarian cancer cells. Gynecol. Oncol. 105, 23-30. doi:10.1016/j.ygyno.2006.11.009

Granato, M., Rizzello, C., Gilardini Montani, M. S., Cuomo, L., Vitillo, M., Santarelli, R., et al. (2017). Quercetin induces apoptosis and autophagy in primary effusion lymphoma cells by inhibiting PI3K/AKT/mTOR and STAT3 signaling pathways. J. Nutr. Biochem. 41, 124-136. doi:10.1016/j.jnutbio.2016. 12.011

Green, D. R., and Llambi, F. (2015). Cell death signaling. Cold Spring Harbor Perspect. Biol. 7, a00608. doi:10.1101/cshperspect.a006080

Grube, S., Ewald, C., Kögler, C., Lawson McLean, A., Kalff, R., and Walter, J. (2018). Achievable central nervous system concentrations of the green tea catechin EGCG induce stress in glioblastoma cells in Vitro. Nutr. Cancer. 70, 1145-1158. doi:10.1080/01635581.2018.1495239

Guamán Ortiz, L. M., Croce, A. L., Aredia, F., Sapienza, S., Fiorillo, G., Syeda, T. M., et al. (2015). Effect of new berberine derivatives on colon cancer cells. Acta Biochim. Biophys. Sinica. 47, 824-833. doi:10.1093/abbs/gmv077

Guan, C., Liu, W., Yue, Y., Jin, H., Wang, X., and Wang, X.-J. (2014). Inhibitory effect of $\beta$-elemene on human breast cancer cells. Int. J. Clin. Exp. Pathol. 7, 3948

Guicciardi, M. E., and Gores, G. J. (2009). Life and death by death receptors. FASEB j. 23, 1625-1637. doi:10.1096/fj.08-111005

Guo, J., Huang, X., Wang, H., and Yang, H. (2015). Celastrol induces autophagy by targeting AR/miR-101 in prostate cancer cells. PLoS One. 10, e0140745. doi:10. 1371/journal.pone.0140745
Gupta, P., and Srivastava, S. K. (2012). Antitumor activity of phenethyl isothiocyanate in HER2-positive breast cancer models. BMC Med. 10, 80. doi:10.1186/1741-7015-10-80

Ha, E. J., Kim, K. Y., Kim, C. E., Jun, D. Y., and Kim, Y. H. (2019). Enhancement of quercetin-induced apoptosis by cotreatment with autophagy inhibitor is associated with augmentation of BAK-dependent mitochondrial pathway in Jurkat T cells. Oxid Med. Cel Longev. 2019, 7989276. doi:10.1155/2019/7989276

Hanna, T. P., King, W. D., Thibodeau, S., Jalink, M., Paulin, G. A., Harvey-Jones, E., et al. (2020). Mortality due to cancer treatment delay: systematic review and meta-analysis. BMJ. 371, m4087. doi:10.1136/bmj.m4087

Hannan, M. A., Dash, R., Haque, M. N., Mohibbullah, M., Sohag, A. A., Rahman, M. A., et al. (2020). Neuroprotective potentials of marine algae and their bioactive metabolites: pharmacological insights and therapeutic advances. Mar. Drugs. 18, 347. doi:10.3390/md18070347

Hartwig, A., Arand, M., Epe, B., Guth, S., Jahnke, G., Lampen, A., et al. (2020). Mode of action-based risk assessment of genotoxic carcinogens. Arch. Toxicol. 94, 1787-1877. doi:10.1007/s00204-020-02733-2

Hassan, M., Watari, H., AbuAlmaaty, A., Ohba, Y., and Sakuragi, N. (2020). Apoptosis and molecular targeting therapy in cancer, BioMed Research International. 2020, 2451249. doi:10.1155/2020/2451249

Henley, S. J., Ward, E. M., Scott, S., Ma, J., Anderson, R. N., Firth, A. U., et al. (2020). Annual report to the nation on the status of cancer, part I: National cancer statistics. Cancer. 126, 2225-2249. doi:10.1002/cncr.32802

Hsin, M. C., Hsieh, Y. H., Wang, P. H., Ko, J. L., Hsin, I. L., and Yang, S. F. (2017). Hispolon suppresses metastasis via autophagic degradation of cathepsin S in cervical cancer cells. Cell Death Dis. 8. 3089. doi:10.1038/cddis.2017.459

Hsu, Y. L., Kuo, P. L., Chiang, L. C., and Lin, C. C. (2004). Involvement of p53, nuclear factor kappaB and Fas/Fas ligand in induction of apoptosis and cell cycle arrest by saikosaponin d in human hepatoma cell lines. Cancer Lett. 213, 213-221. doi:10.1016/j.canlet.2004.03.044

Huang, Y.-H., Sun, Y., Huang, F.-Y., Li, Y.-N., Wang, C.-C., Mei, W.-L., et al. (2017). Toxicarioside $\mathrm{O}$ induces protective autophagy in a sirtuin-1-dependent manner in colorectal cancer cells. Oncotarget. 8, 52783. doi:10.18632/oncotarget.17189

Hui, C., Bin, Y., Xiaoping, Y., Long, Y., Chunye, C., Mantian, M., et al. (2010). Anticancer activities of an anthocyanin-rich extract from black rice against breast cancer cells in vitro and in vivo. Nutr. Cancer. 62, 1128-1136. doi:10. 1080/01635581.2010.494821

Hung, J. Y., Hsu, Y. L., Li, C. T., Ko, Y. C., Ni, W. C., Huang, M. S., et al. (2009). 6Shogaol, an active constituent of dietary ginger, induces autophagy by inhibiting the AKT/mTOR pathway in human non-small cell lung cancer A549 cells. J. Agric. Food Chem. 57, 9809-9816. doi:10.1021/jf902315e

Hurley, J. H., and Young, L. N. (2017). Mechanisms of autophagy initiation. Annu. Rev. Biochem. 86, 225-244. doi:10.1146/annurev-biochem-061516-044820

Jahanafrooz, Z., Motamed, N., Rinner, B., Mokhtarzadeh, A., and Baradaran, B. (2018). Silibinin to improve cancer therapeutic, as an apoptotic inducer, autophagy modulator, cell cycle inhibitor, and microRNAs regulator. Life Sci. 213, 236-247. doi:10.1016/j.lfs.2018.10.009

Jang, H. J., Yang, K. E., Hwang, I. H., Huh, Y. H., Kim, D. J., Yoo, H. S., et al. (2019). Cordycepin inhibits human ovarian cancer by inducing autophagy and apoptosis through Dickkopf-related protein $1 / \beta$-catenin signaling. Am. J. Transl Res. 11, 6890-6906.

Jin, H. R., Zhao, J., Zhang, Z., Liao, Y., Wang, C. Z., Huang, W. H., et al. (2012). The antitumor natural compound falcarindiol promotes cancer cell death by inducing endoplasmic reticulum stress. Cel Death Dis. 3, e376. doi:10.1038/cddis.2012.122

Johnson, R., Shabalala, S., Louw, J., Kappo, A. P., and Muller, C. J. F. (2017). Aspalathin reverts doxorubicin-induced cardiotoxicity through increased autophagy and decreased expression of p53/mTOR/p62 signaling. Molecules. 22. 1589. doi:10.3390/molecules22101589

Jung, E. M., Lim, J. H., Lee, T. J., Park, J. W., Choi, K. S., and Kwon, T. K. (2005). Curcumin sensitizes tumor necrosis factor-related apoptosis-inducing ligand (TRAIL)-induced apoptosis through reactive oxygen species-mediated upregulation of death receptor 5 (DR5). Carcinogenesis. 26, 1905-1913. doi:10.1093/carcin/bgil67

Jung, S., Jeong, H., and Yu, S.-W. (2020). Autophagy as a decisive process for cell death. Exp. Mol. Med. 52, 921-930. doi:10.1038/s12276-020-0455-4

Kardideh, B., Samimi, Z., Norooznezhad, F., Kiani, S., and Mansouri, K. (2019). Autophagy, cancer and angiogenesis: where is the link? Cell Biosci. 9, 65. doi:10. 1186/s13578-019-0327-6 
Karius, T., Schnekenburger, M., Dicato, M., and Diederich, M. (2012). MicroRNAs in cancer management and their modulation by dietary agents. Biochem. Pharmacol. 83, 1591-1601. doi:10.1016/j.bcp.2012.02.004

Khaltaev, N., and Axelrod, S. (2020). Global lung cancer mortality trends and lifestyle modifications: preliminary analysis. Chin. Med J-Peking. 133, 1526-1532. doi: 10.1097/Cm9.0000000000000918

Kim, E. S., Shin, J. H., Seok, S. H., Kim, J. B., Chang, H., Park, S. J., et al. (2013). Autophagy mediates anti-melanogenic activity of $3^{\prime}$-ODI in B16F1 melanoma cells. Biochem. Biophysical Res. Commun. 442, 165-170. doi:10.1016/j.bbrc. 2013.11.048

Kim, R. (2005). Recent advances in understanding the cell death pathways activated by anticancer therapy. Cancer. 103, 1551-1560. doi:10.1002/cncr. 20947

Kotani, T., Kirisako, H., Koizumi, M., Ohsumi, Y., and Nakatogawa, H. (2018). The Atg2-Atg18 complex tethers pre-autophagosomal membranes to the endoplasmic reticulum for autophagosome formation. Proc. Natl. Acad. Sci. USA. 115, 10363-10368. doi:10.1073/pnas.1806727115

Krishnan, S., Shrestha, Y., Jayatunga, D. P. W., Rea, S., Martins, R., and Bharadwaj, P. (2020). Activate or inhibit? Implications of autophagy modulation as a therapeutic strategy for alzheimer's disease. Int. J. Mol. Sci. 21, 6739 doi:10. 3390/ijms21186739

Kumar, D., Shankar, S., and Srivastava, R. K. (2013). Rottlerin-induced autophagy leads to the apoptosis in breast cancer stem cells: molecular mechanisms. Mol. Cancer. 12, 171. doi:10.1186/1476-4598-12-171

Kwon, Y. H., Bishayee, K., Rahman, M. A., Hong, J. S., Lim, S. S., and Huh, S. O. (2015). Morus alba accumulates reactive oxygen species to initiate apoptosis via FOXO-caspase 3-dependent pathway in neuroblastoma cells. Mol. Cell. 38, 630-637. doi:10.14348/molcells.2015.0030

Lancon, A., Kaminski, J., Tili, E., Michaille, J. J., and Latruffe, N. (2012). Control of MicroRNA expression as a new way for resveratrol to deliver its beneficial effects. J. Agr Food Chem. 60, 8783-8789. doi:10.1021/jf301479v

Lao, Y., Wan, G., Liu, Z., Wang, X., Ruan, P., Xu, W., et al. (2014). The natural compound oblongifolin $\mathrm{C}$ inhibits autophagic flux and enhances antitumor efficacy of nutrient deprivation. Autophagy. 10, 736-749. doi:10.4161/auto. 28034

Law, B. Y., Wang, M., Ma, D. L., Al-Mousa, F., Michelangeli, F., Cheng, S. H., et al. (2010). Alisol B, a novel inhibitor of the sarcoplasmic/endoplasmic reticulum $\mathrm{Ca}(2+)$ ATPase pump, induces autophagy, endoplasmic reticulum stress, and apoptosis. Mol. Cancer Ther. 9, 718-730. doi:10.1158/1535-7163.mct-09-0700

Law, B. Y. K., Mok, S. W. F., Chen, J., Michelangeli, F., Jiang, Z. H., Han, Y., et al. (2017). N-desmethyldauricine induces autophagic cell death in apoptosisdefective cells via $\mathrm{Ca}(2+)$ mobilization. Front. Pharmacol. 8, 388. doi:10. 3389/fphar.2017.00388

Lee, Y. J., Kim, N.-Y., Suh, Y.-A., and Lee, C. (2011). Involvement of ROS in curcumin-induced autophagic cell death. Korean J. Physiol. Pharmacol. 15, 1-7. doi:10.4196/kjpp.2011.15.1.1

Lee, E. B., Cheon, M. G., Cui, J., Lee, Y. J., Seo, E. K., and Jang, H. H. (2017). The quinone-based derivative, HMNQ induces apoptotic and autophagic cell death by modulating reactive oxygen species in cancer cells. Oncotarget. 8, 99637-99648. doi:10.18632/oncotarget.21005

Levine, B., and Kroemer, G. (2008). Autophagy in the pathogenesis of disease. Cell. 132, 27-42. doi:10.1016/j.cell.2007.12.018

Li, W., Nie, S., Yu, Q., and Xie, M. (2009). (-)-Epigallocatechin-3-gallate induces apoptosis of human hepatoma cells by mitochondrial pathways related to reactive oxygen species. J. Agric. Food Chem. 57, 6685-6691. doi:10.1021/ jf901396f

Li, L., Yue, G. G., Lau, C. B., Sun, H., Fung, K. P., Leung, P. C., et al. (2012). Eriocalyxin $\mathrm{B}$ induces apoptosis and cell cycle arrest in pancreatic adenocarcinoma cells through caspase-and p53-dependent pathways. Toxicol. Appl. Pharmacol. 262, 80-90.

Li, F., Ma, Z., Guan, Z., Chen, Y., Wu, K., Guo, P., et al. (2015). Autophagy induction by silibinin positively contributes to its anti-metastatic capacity via AMPK/mTOR pathway in renal cell carcinoma. Int. J. Mol. Sci. 16, 8415-8429. doi:10.3390/ijms16048415

Lin, X., Wu, G., Huo, W.-Q., Zhang, Y., and Jin, F.-S. (2012). Resveratrol induces apoptosis associated with mitochondrial dysfunction in bladder carcinoma cells. Int. J. Urol. 19, 757-764. doi:10.1111/j.1442-2042.2012.03024.x
Lin, C.-M., Chen, H.-H., Lin, C.-A., Wu, H.-C., Sheu, J. J.-C., and Chen, H.-J. (2017a). Apigenin-induced lysosomal degradation of $\beta$-catenin in Wnt/ $\beta$-catenin signaling. Scientific Rep. 7, 1-17. doi:10.1038/s41598-017-00409-Z

Lin, Y.-T., Wang, H.-C., Hsu, Y.-C., Cho, C.-L., Yang, M.-Y., and Chien, C.-Y. (2017b). Capsaicin induces autophagy and apoptosis in human nasopharyngeal carcinoma cells by downregulating the PI3K/AKT/mTOR pathway. Int. J. Mol. Sci. 18, 1343. doi:10.3390/ijms18071343

Ling, M. T., Luk, S. U., Al-Ejeh, F., and Khanna, K. K. (2012). Tocotrienol as a potential anticancer agent. Carcinogenesis. 33, 233-239. doi:10.1093/carcin/ bgr261

Liu, J., Zheng, L., Zhong, J., Wu, N., Liu, G., and Lin, X. (2014). Oleanolic acid induces protective autophagy in cancer cells through the JNK and mTOR pathways. Oncol. Rep. 32, 567-572. doi:10.3892/or.2014.3239

Liu, S., Xu, Z. L., Sun, L., Liu, Y., Li, C. C., Li, H. M., et al. (2016). (-)-Epigallocatechin-3-gallate induces apoptosis in human pancreatic cancer cells via PTEN. Mol. Med. Rep. 14, 599-605. doi:10.3892/mmr.2016.5277

Liu, F., Gao, S., Yang, Y., Zhao, X., Fan, Y., Ma, W., et al. (2018). Antitumor activity of curcumin by modulation of apoptosis and autophagy in human lung cancer A549 cells through inhibiting PI3K/Akt/mTOR pathway. Oncol. Rep. 39, 1523-1531. doi:10.3892/or.2018.6188

Lopez, J., and Tait, S. W. G. (2015). Mitochondrial apoptosis: killing cancer using the enemy within. Br. J. Cancer. 112, 957-962. doi:10.1038/bjc.2015.85

Lu, T., Gu, M., Zhao, Y., Zheng, X., and Xing, C. (2017). Autophagy contributes to falcarindiol-induced cell death in breast cancer cells with enhanced endoplasmic reticulum stress. PLoS One. 12, e0176348. doi:10.1371/journal. pone. 0176348

Ma, X., and Ning, S. (2019). Cyanidin-3-glucoside attenuates the angiogenesis of breast cancer via inhibiting STAT3/VEGF pathway. Phytotherapy Res. 33, 81-89. doi:10.1002/ptr.6201

Mai, T. T., Moon, J., Song, Y., Viet, P. Q., Phuc, P. V., Lee, J. M., et al. (2012). Ginsenoside F2 induces apoptosis accompanied by protective autophagy in breast cancer stem cells. Cancer Lett. 321, 144-153. doi:10.1016/j.canlet.2012. 01.045

Markham, M. J., Wachter, K., Agarwal, N., Bertagnolli, M. M., Chang, S. M., Dale, W., et al. (2020). Clinical cancer advances 2020: annual report on progress against cancer from the American society of clinical oncology. Jco. 38, 1081. doi:10.1200/jco.19.03141

Masuelli, L., Benvenuto, M., Stefano, E. D., Mattera, R., Fantini, M., Feudis, G. D., et al. (2017). Curcumin blocks autophagy and activates apoptosis of malignant mesothelioma cell lines and increases the survival of mice intraperitoneally transplanted with a malignant mesothelioma cell line. Oncotarget. 8, 34405. doi:10.18632/oncotarget.14907

Minto, R. E., and Blacklock, B. J. (2008). Biosynthesis and function of polyacetylenes and allied natural products. Prog. lipid Res. 47, 233-306. doi:10.1016/j.plipres.2008.02.002

Mitra, S., and Dash, R. (2018). Natural products for the management and prevention of breast cancer, evidence-based complementary and alternative medicine, Evid Based Complement Alternat Med. 2018, 8324696. doi:10.1155/ 2018/8324696

Mohapatra, P., Preet, R., Das, D., Satapathy, S. R., Choudhuri, T., Wyatt, M. D., et al. (2012). Quinacrine-mediated autophagy and apoptosis in colon cancer cells is through a p53- and p21-dependent mechanism. Oncol. Res. 20, 81-91. doi: $10.3727 / 096504012 \times 13473664562628$

Moni, A., Iqbal, A., and Uddin, M. J. (2018). Resveratrol attenuates inflammation through tristetraprolin expression in human hepatocytes. J. Adv. Biotechnol. Exp. Ther. 1, 78-82. doi:10.5455/jabet.2018.d14

Moosavi, M. A., Haghi, A., Rahmati, M., Taniguchi, H., Mocan, A., Echeverría, J., et al. (2018). Phytochemicals as potent modulators of autophagy for cancer therapy. Cancer Lett. 424, 46-69. doi:10.1016/j.canlet.2018.02.030

Mujumdar, N., Mackenzie, T. N., Dudeja, V., Chugh, R., Antonoff, M. B., BorjaCacho, D., et al. (2010). Triptolide induces cell death in pancreatic cancer cells by apoptotic and autophagic pathways. Gastroenterology. 139, 598-608. doi:10. 1053/j.gastro.2010.04.046

Naumann, P., Fortunato, F., Zentgraf, H., Büchler, M. W., Herr, I., and Werner, J. (2011). Autophagy and cell death signaling following dietary sulforaphane act independently of each other and require oxidative stress in pancreatic cancer. Int. J. Oncol. 39, 101-109. doi:10.3892/ijo.2011.1025 
Newman, D. J., and Cragg, G. M. (2016). Natural products as sources of new drugs from 1981 to 2014. J. Nat. Prod. 79, 629-661. doi:10.1021/acs.jnatprod.5b01055

Panda, P. K., Mukhopadhyay, S., Das, D. N., Sinha, N., Naik, P. P., and Bhutia, S. K. (2015). Mechanism of autophagic regulation in carcinogenesis and cancer therapeutics. Semin. Cel Developmental Biol. 39, 43-55. doi:10.1016/j. semcdb.2015.02.013

Patra, S., Mishra, S. R., Behera, B. P., Mahapatra, K. K., Panigrahi, D. P., Bhol, C. S., et al. (2020). Autophagy-modulating phytochemicals in cancer therapeutics: current evidences and future perspectives. Semin. Cancer Biol. doi:10.1016/j. semcancer.2020.05.008

Peng, P. L., Kuo, W. H., Tseng, H. C., and Chou, F. P. (2008). Synergistic tumorkilling effect of radiation and berberine combined treatment in lung cancer: the contribution of autophagic cell death. Int. J. Radiat. Oncol. Biol. Phys. 70, 529-542. doi:10.1016/j.ijrobp.2007.08.034

Pollier, J., and Goossens, A. (2012). Oleanolic acid, Phytochemistry. 77, 10-15. doi:10.1016/j.phytochem.2011.12.022

Radhakrishnan, E., Bava, S. V., Narayanan, S. S., Nath, L. R., Thulasidasan, A. K. T., Soniya, E. V., et al. (2014). [6]-Gingerol induces caspase-dependent apoptosis and prevents PMA-induced proliferation in colon cancer cells by inhibiting MAPK/AP-1 signaling. PloS one. 9, e104401. doi:10.1371/journal.pone.0104401

Rahman, M. A., and Rhim, H. (2017). Therapeutic implication of autophagy in neurodegenerative diseases. BMB Rep. 50, 345-354. doi:10.5483/BMBRep.2017. 50.7.069

Rahman, M. A., Kim, N. H., Kim, S. H., Oh, S. M., and Huh, S. O. (2012a). Antiproliferative and cytotoxic effects of resveratrol in mitochondria-mediated apoptosis in rat B103 neuroblastoma cells. Korean J. Physiol. Pha. 16, 321-326. doi:10.4196/kjpp.2012.16.5.321

Rahman, M. A., Kim, N. H., Yang, H., and Huh, S. O. (2012b). Angelicin induces apoptosis through intrinsic caspase-dependent pathway in human SH-SY5Y neuroblastoma cells. Mol. Cell Biochem. 369, 95-104. doi:10.1007/s11010-0121372-1

Rahman, M. A., Kim, N. H., and Huh, S. O. (2013). Cytotoxic effect of gambogic acid on SH-SY5Y neuroblastoma cells is mediated by intrinsic caspasedependent signaling pathway. Mol. Cel Biochem. 377, 187-196. doi:10.1007/ s11010-013-1584-z

Rahman, M. A., Yang, H., Kim, N. H., and Huh, S. O. (2014). Induction of apoptosis by Dioscorea nipponica Makino extracts in human SH-SY5Y neuroblastoma cells via mitochondria-mediated pathway. Anim. Cell Syst. 18, 41-51. doi:10.1080/19768354.2014.880372

Rahman, M. A., Hong, J. S., and Huh, S. O. (2015). Antiproliferative properties of Saussurea lappa Clarke root extract in SH-SY5Y neuroblastoma cells via intrinsic apoptotic pathway. Anim. Cell Syst 19, 119-126. doi:10.1080/ 19768354.2015.1008041

Rahman, M. A., Bishayee, K., Habib, K., Sadra, A., and Huh, S. O. (2016a). 18 alpha-Glycyrrhetinic acid lethality for neuroblastoma cells via de-regulating the Beclin-1/Bcl-2 complex and inducing apoptosis. Biochem. Pharmacol. 117, 97-112. doi:10.1016/j.bcp.2016.08.006

Rahman, M. A., Bishayee, K., and Huh, S. O. (2016b). Angelica polymorpha Maxim induces apoptosis of human SH-SY5Y neuroblastoma cells by regulating an intrinsic caspase pathway. Mol. Cell. 39, 119-128. doi:10.14348/molcells.2016.2232

Rahman, M. A., Bishayee, K., Sadra, A., and Huh, S. O. (2017). Oxyresveratrol activates parallel apoptotic and autophagic cell death pathways in neuroblastoma cells. Biochim. Biophys. Acta Gen. Subj. 1861, 23-36. doi:10. 1016/j.bbagen.2016.10.025

Rahman, M. A., Hwang, H., Nah, S. Y., and Rhim, H. (2020). Gintonin stimulates autophagic flux in primary cortical astrocytes. J. Ginseng Res. 44, 67-78. doi:10. 1016/j.jgr.2018.08.004

Rahman, M. A., Rahman, M. H., Hossain, M. S., Biswas, P., Islam, R., Uddin, M. J., et al. (2020a). Molecular insights into the multifunctional role of natural compounds: autophagy modulation and cancer prevention. Biomedicines. 8 . 517. doi:10.3390/biomedicines8110517

Rahman, M. A., Rahman, M. R., Zaman, T., Uddin, M. S., Islam, R., Abdel-Daim, M. M., et al. (2020b). Emerging potential of naturally occurring autophagy modulators against neurodegeneration. Curr. Pharm. Des. 26, 772-779. doi:10. 2174/1381612826666200107142541

Raj, L., Ide, T., Gurkar, A. U., Foley, M., Schenone, M., Li, X., et al. (2011). Selective killing of cancer cells by a small molecule targeting the stress response to ROS. Nature. 475, 231-234. doi:10.1038/nature10167
Rajendran, P., Nandakumar, N., Rengarajan, T., Palaniswami, R., Gnanadhas, E. N., Lakshminarasaiah, U., et al. (2014). Antioxidants and human diseases. Clin. Chim. Acta 436, 332-347. doi:10.1016/j.cca.2014.06.004

Rasul, A., Yu, B., Zhong, L., Khan, M., Yang, H., and Ma, T. (2012). Cytotoxic effect of evodiamine in SGC-7901 human gastric adenocarcinoma cells via simultaneous induction of apoptosis and autophagy. Oncol. Rep. 27, 1481-1487. doi:10.3892/or.2012.1694

Ren, G., Sha, T., Guo, J., Li, W., Lu, J., and Chen, X. (2015). Cucurbitacin B induces DNA damage and autophagy mediated by reactive oxygen species (ROS) in MCF-7 breast cancer cells. J. Nat. medicines. 69, 522-530. doi:10.1007/s11418015-0918-4

Rubinsztein, D. C., Shpilka, T., and Elazar, Z. (2012). Mechanisms of autophagosome biogenesis. Curr. Biol. 22, R29-R34. doi:10.1016/j.cub.2011. 11.034

Russell, L. H., Jr., Mazzio, E., Badisa, R. B., Zhu, Z. P., Agharahimi, M., Oriaku, E. T., et al. (2012). Autoxidation of gallic acid induces ROSdependent death in human prostate cancer LNCaP cells. Anticancer Res. 32, 1595-1602.

Saibu, M., Sagar, S., Green, I., Ameer, F., and Meyer, M. (2014). Evaluating the cytotoxic effects of novel quinone compounds. Anticancer Res. 34, 4077-4086.

Sak, K. (2012). Chemotherapy and dietary phytochemical agents, Chemotherapy research and practice. Chemother Res Pract. 2012, 282570. doi:10.1155/2012/ 282570

Sak, K. (2014). Site-specific anticancer effects of dietary flavonoid quercetin. Nutr. Cancer. 66, 177-193. doi:10.1080/01635581.2014.864418

Sanford, N. N., Sher, D. J., Xu, X., Ahn, C., D'Amico, A. V., Aizer, A. A., et al. (2020), Alcohol use among patients with cancer and survivors in the United States, 2000-2017, J. Natl. Compr. Canc Ne. 18, 69. doi:10.6004/ jncen.2019.7341

Santana-Codina, N., Mancias, J. D., and Kimmelman, A. C. (2017). The role of autophagy in cancer. Annu. Rev. Cancer Biol. 1, 19-39. doi:10.1146/annurevcancerbio-041816-122338

Satoh, M., Takemura, Y., Hamada, H., Sekido, Y., and Kubota, S. (2013). EGCG induces human mesothelioma cell death by inducing reactive oxygen species and autophagy. Cancer Cel Int. 13, 19. doi:10.1186/1475-2867-13-19

Schirrmacher, V. (2019). From chemotherapy to biological therapy: a review of novel concepts to reduce the side effects of systemic cancer treatment (Review). Int. J. Oncol. 54, 407-419. doi:10.3892/ijo.2018.4661

Sena, Laura. A., and Chandel, Navdeep. S. (2012). Physiological roles of mitochondrial reactive oxygen species. Mol. Cel. 48, 158-167. doi:10.1016/j. molcel.2012.09.025

Shankar, S., Chen, Q., Siddiqui, I., Sarva, K., and Srivastava, R. K. (2007). Sensitization of TRAIL-resistant LNCaP cells by resveratrol $(3,4,5$ trihydroxystilbene): molecular mechanisms and therapeutic potential. J. Mol. Signal. 2, 7. doi:10.1186/1750-2187-2-7

Shin, S. W., Kim, S. Y., and Park, J. W. (2012). Autophagy inhibition enhances ursolic acid-induced apoptosis in PC3 cells. Biochim. Biophys. Acta. 1823, 451-457. doi:10.1016/j.bbamcr.2011.10.014

Shukla, Y., and Singh, M. (2007). Cancer preventive properties of ginger: a brief review. Food Chem Toxicol. 45, 683-690. doi:10.1016/j.fct.2006.11.002

Siddiqui, I. A., Asim, M., Hafeez, B. B., Adhami, V. M., Tarapore, R. S., and Mukhtar, H. (2011). Green tea polyphenol EGCG blunts androgen receptor function in prostate cancer. FASEB J. : official Publ. Fed. Am. Societies Exp. Biol. 25, 1198-1207. doi:10.1096/fj.10-167924

Siegel, R. L., Miller, K. D., and Jemal, A. (2020). Cancer statistics, 2020. CA A. Cancer J. Clin. 70, 7-30. doi:10.3322/caac.21590

Singh, R., and Cuervo, A. M. (2011). Autophagy in the cellular energetic balance. Cel Metab. 13, 495-504. doi:10.1016/j.cmet.2011.04.004

Stadlbauer, S., Steinborn, C., Klemd, A., Hattori, F., Ohmori, K., Suzuki, K., et al. (2018). Impact of green tea catechin ECG and its synthesized fluorinated analogue on prostate cancer cells and stimulated immunocompetent cells. Planta Med. 84, 813-819. doi:10.1055/s-0044-102099

Su, M., Mei, Y., and Sinha, S. (2013). Role of the crosstalk between autophagy and apoptosis in cancer. J. Oncol. 2013, 102735. doi:10.1155/2013/102735

Suh, Y., Afaq, F., Khan, N., Johnson, J. J., Khusro, F. H., and Mukhtar, H. (2010). Fisetin induces autophagic cell death through suppression of mTOR signaling pathway in prostate cancer cells. Carcinogenesis. 31, 1424-1433. doi:10.1093/ carcin/bgq115 
Sun, C. Y., Zhu, Y., Li, X. F., Tang, L. P., Su, Z. Q., Wang, X. Q., et al. (2017a). Norcantharidin alone or in combination with crizotinib induces autophagic cell death in hepatocellular carcinoma by repressing c-Met-mTOR signaling. Oncotarget. 8, 114945-114955. doi:10.18632/oncotarget.22935

Sun, Z. L., Dong, J. L., and Wu, J. (2017b). Juglanin induces apoptosis and autophagy in human breast cancer progression via ROS/JNK promotion. Biomed. Pharmacother. 85, 303-312. doi:10.1016/j.biopha.2016.11.030

Sun, L. R., Zhou, W., Zhang, H. M., Guo, Q. S., Yang, W., Li, B. J., et al. (2019). Modulation of multiple signaling pathways of the plant-derived natural products in cancer. Front. Oncol. 9, 1153. doi:10.3389/fonc.2019.01153

Surichan, S., Arroo, R. R., Tsatsakis, A. M., and Androutsopoulos, V. P. (2018). Tangeretin inhibits the proliferation of human breast cancer cells via CYP1A1/ CYP1B1 enzyme induction and CYP1A1/CYP1B1-mediated metabolism to the product 4' hydroxy tangeretin. Toxicol In Vitro. 50, 274-284. doi:10.1016/j.tiv. 2018.04.001

Tang, K. D., Liu, J., Russell, P. J., Clements, J. A., and Ling, M. T. (2019). Gammatocotrienol induces apoptosis in prostate cancer cells by targeting the ang-1/tie2 signalling pathway. Int. J. Mol. Sci. 20, 1164. doi:10.3390/ijms20051164

Thorburn, A., Thamm, D. H., and Gustafson, D. L. (2014). Autophagy and cancer therapy. Mol. Pharmacol. 85, 830-838. doi:10.1124/mol.114.091850

Tompkins, K. D., and Thorburn, A. (2019). Regulation of apoptosis by autophagy to enhance cancer therapy. Yale J. Biol. Med. 92, 707-718.

Tsai, C.-Y., Chen, C.-Y., Chiou, Y.-H., Shyu, H.-W., Lin, K.-H., Chou, M.-C., et al. (2018). Epigallocatechin-3-gallate suppresses human herpesvirus 8 replication and induces ROS leading to apoptosis and autophagy in primary effusion lymphoma cells. Int. J. Mol. Sci. 19, 16. doi:10.3390/ijms19010016

Tundis, R., Bonesi, M., Deguin, B., Loizzo, M. R., Menichini, F., Conforti, F., et al. (2009). Cytotoxic activity and inhibitory effect on nitric oxide production of triterpene saponins from the roots of Physospermum verticillatum (Waldst \& Kit) (Apiaceae). Bioorg. Med. Chem. 17, 4542-4547. doi:10.1016/j.bmc.2009. 05.006

Uddin, M. S., Al Mamun, A., Jakaria, M., Thangapandiyan, S., Ahmad, J., Rahman, M. A., et al. (2020). Emerging promise of sulforaphane-mediated Nrf2 signaling cascade against neurological disorders. Sci. Total Environ. 707, 135624. doi:10. 1016/j.scitotenv.2019.135624

Velazquez, A. F. C., and Jackson, W. T. (2018). So many roads: the multifaceted regulation of autophagy induction. Mol. Cel Biol. 38, e00303-18. doi:10.1128/ MCB.00303-18

Wang, N., Feng, Y., Zhu, M., Tsang, C. M., Man, K., Tong, Y., et al. (2010). Berberine induces autophagic cell death and mitochondrial apoptosis in liver cancer cells: the cellular mechanism. J. Cell. Biochem. 111, 1426-1436. doi:10. $1002 /$ jcb. 22869

Wang, Z., Jiang, C., Chen, W., Zhang, G., Luo, D., Cao, Y., et al. (2014). Baicalein induces apoptosis and autophagy via endoplasmic reticulum stress in hepatocellular carcinoma cells. Biomed Res Int. 2014, 732516. doi:10.1155/ 2014/732516

Wang, F., Mao, Y., You, Q., Hua, D., and Cai, D. (2015). Piperlongumine induces apoptosis and autophagy in human lung cancer cells through inhibition of PI3K/Akt/mTOR pathway. Int. J. immunopathology Pharmacol. 28, 362-373. doi:10.1177/0394632015598849

Wang, J., Qi, Q., Feng, Z., Zhang, X., Huang, B., Chen, A., et al. (2016a). Berberine induces autophagy in glioblastoma by targeting the AMPK/mTOR/ULK1pathway. Oncotarget. 7, 66944. doi:10.18632/oncotarget.11396

Wang, R., Ma, L., Weng, D., Yao, J., Liu, X., and Jin, F. (2016b). Gallic acid induces apoptosis and enhances the anticancer effects of cisplatin in human small cell lung cancer $\mathrm{H} 446$ cell line via the ROS-dependent mitochondrial apoptotic pathway. Oncol. Rep. 35, 3075-3083. doi:10.3892/or.2016.4690

Wang, X., Zhang, H., and Chen, X. (2019). Drug resistance and combating drug resistance in cancer. Cancer Drug Resist. 2, 141-160. doi:10.20517/cdr.2019.10

Wang, D., He, X., Wang, D., Peng, P., Xu, X., Gao, B., et al. (2020). Quercetin suppresses apoptosis and attenuates intervertebral disc degeneration via the SIRT1-autophagy pathway. Front Cel Dev Biol. 8, 613006. doi:10.3389/fcell. 2020.613006

Wei, Y., and Huang, J. (2019). Role of estrogen and its receptors mediatedautophagy in cell fate and human diseases. J. Steroid Biochem. 191, 105380. doi:10.1016/j.jsbmb.2019.105380
Whitlock, N. C., and Baek, S. J. (2012). The anticancer effects of resveratrol: modulation of transcription factors. Nutr. Cancer. 64, 493-502. doi:10.1080/ 01635581.2012 .667862

WHO (2018). https://www.who.int/news-room/fact-sheets/detail/cancer

Wong, V. K., Li, T., Law, B. Y., Ma, E. D., Yip, N. C., Michelangeli, F., et al. (2013). Saikosaponin-d, a novel SERCA inhibitor, induces autophagic cell death in apoptosis-defective cells. Cel Death Dis. 4, e720. doi:10.1038/cddis.2013.217

Wu, P. P., Kuo, S. C., Huang, W. W., Yang, J. S., Lai, K. C., Chen, H. J., et al. (2009). (-)-Epigallocatechin gallate induced apoptosis in human adrenal cancer NCIH295 cells through caspase-dependent and caspase-independent pathway. Anticancer Res. 29, 1435-1442.

Wu, J. Q., Kosten, T. R., and Zhang, X. Y. (2013). Free radicals, antioxidant defense systems, and schizophrenia. Prog Neuropsychopharmacol Biol Psychiatry. 46, 200-206. doi:10.1016/j.pnpbp.2013.02.015

Wu, M., Lao, Y., Xu, N., Wang, X., Tan, H., Fu, W., et al. (2015). Guttiferone K induces autophagy and sensitizes cancer cells to nutrient stress-induced cell death. Phytomedicine. 22, 902-910. doi:10.1016/j.phymed.2015.06.008

Wu, Q., Kroon, P. A., Shao, H., Needs, P. W., and Yang, X. (2018). Differential effects of quercetin and two of its derivatives, isorhamnetin and isorhamnetin3-glucuronide, in inhibiting the proliferation of human breast-cancer MCF-7 cells. J. Agric. Food Chem. 66, 7181-7189. doi:10.1021/acs.jafc.8b02420

Xu, G., Feng, C., Zhou, Y., Han, Q. B., Qiao, C. F., Huang, S. X., et al. (2008). Bioassay and ultraperformance liquid chromatography/mass spectrometry guided isolation of apoptosis-inducing benzophenones and xanthone from the pericarp of Garcinia yunnanensis Hu. J. Agric. Food Chem. 56, 11144-11150. doi:10.1021/jf802690g

Xue, L., Zhang, W. J., Fan, Q. X., and Wang, L. X. (2018). Licochalcone A inhibits PI3K/Akt/mTOR signaling pathway activation and promotes autophagy in breast cancer cells. Oncol. Lett. 15, 1869-1873. doi:10.3892/ol.2017.7451

Yamagata, K., Xie, Y., Suzuki, S., and Tagami, M. (2015). Epigallocatechin-3-gallate inhibits VCAM-1 expression and apoptosis induction associated with LC3 expressions in TNFa-stimulated human endothelial cells. Phytomedicine. 22, 431-437. doi:10.1016/j.phymed.2015.01.011

Yang, G.-Y., Liao, J., Kim, K., Yurkow, E. J., and Yang, C. S. (1998). Inhibition of growth and induction of apoptosis in human cancer cell lines by tea polyphenols. Carcinogenesis. 19, 611-616. doi:10.1093/carcin/19.4.611

Yang, C., Zhao, L., Yuan, W., and Wen, J. (2017). Cordycepin induces apoptotic cell death and inhibits cell migration in renal cell carcinoma via regulation of microRNA-21 and PTEN phosphatase. Biomed. Res. 38, 313-320. doi:10.2220/ biomedres.38.313

Yang, J., Pi, C., and Wang, G. (2018). Inhibition of PI3K/Akt/mTOR pathway by apigenin induces apoptosis and autophagy in hepatocellular carcinoma cells. Biomed. Pharmacother. 103, 699-707. doi:10.1016/j.biopha.2018.04.072

Ye, C., Zhang, C., Huang, H., Yang, B., Xiao, G., Kong, D., et al. (2018). The natural compound myricetin effectively represses the malignant progression of prostate cancer by inhibiting PIM1 and disrupting the PIM1/CXCR4 interaction, cellular physiology and biochemistry. Cell Physiol Biochem. 48, 1230-1244. doi:10.1159/000492009

Yu, R., Zhang, Z. Q., Wang, B., Jiang, H. X., Cheng, L., and Shen, L. M. (2014). Berberine-induced apoptotic and autophagic death of HepG2 cells requires AMPK activation. Cancer Cel. Int. 14, 49. doi:10.1186/1475-2867-14-49

Zhang, J. F., Liu, J. J., Liu, P. Q., Lin, D. J., Li, X. D., and Chen, G. H. (2006). Oridonin inhibits cell growth by induction of apoptosis on human hepatocelluar carcinoma BEL-7402 cells. Hepatol. Res. 35, 104-110. doi:10. 1016/j.hepres.2006.03.007

Zhang, X., Zhu, Y., Duan, W., Feng, C., and He, X. (2015). Allicin induces apoptosis of the MGC-803 human gastric carcinoma cell line through the p38 mitogenactivated protein kinase/caspase-3 signaling pathway. Mol. Med. Rep. 11, 2755-2760. doi:10.3892/mmr.2014.3109

Zhang, Z., Liu, T., Yu, M., Li, K., and Li, W. (2018). The plant alkaloid tetrandrine inhibits metastasis via autophagy-dependent $\mathrm{Wnt} / \beta$-catenin and metastatic tumor antigen 1 signaling in human liver cancer cells. J. Exp. Clin. Cancer Res. 37, 7. doi:10.1186/s13046-018-0678-6

Zhang, S., Cao, M., and Fang, F. (2020a). The role of epigallocatechin-3-gallate in autophagy and endoplasmic reticulum stress (ERS)-Induced apoptosis of human diseases. Med. Sci. Monit. 26, e924558. doi:10.12659/MSM.924558 
Zhang, Z., Zhou, L., Xie, N., Nice, E. C., Zhang, T., Cui, Y. P., et al. (2020b), Overcoming cancer therapeutic bottleneck by drug repurposing. Signal Transduct Target Ther. 5, 113. doi:10.1038/s41392-020-00213-8

Zhong, Y., Krisanapun, C., Lee, S.-H., Nualsanit, T., Sams, C., Peungvicha, P., et al. (2010). Molecular targets of apigenin in colorectal cancer cells: involvement of p21, NAG-1 and p53. Eur. J. Cancer 46, 3365-3374. doi:10.1016/j.ejca.2010. 07.007

Zhu, Y., Rao, Q., Zhang, X., and Zhou, X. (2018). Galangin induced antitumor effects in human kidney tumor cells mediated via mitochondrial mediated apoptosis, inhibition of cell migration and invasion and targeting PI3K/AKT/ mTOR signalling pathway. J BUON. 23, 795-799.
Conflict of Interest: The authors declare that the research was conducted in the absence of any commercial or financial relationships that could be construed as a potential conflict of interest.

Copyright (C) 2021 Rahman, Hannan, Dash, Rahman, Islam, Uddin, Sohag, Rahman and Rhim. This is an open-access article distributed under the terms of the Creative Commons Attribution License (CC BY). The use, distribution or reproduction in other forums is permitted, provided the original author(s) and the copyright owner(s) are credited and that the original publication in this journal is cited, in accordance with accepted academic practice. No use, distribution or reproduction is permitted which does not comply with these terms. 